NBER WORKING PAPER SERIES

\title{
DO MARKETS REDUCE COSTS? ASSESSING THE IMPACT OF REGULATORY RESTRUCTURING ON U.S. ELECTRIC GENERATION EFFICIENCY
}

\author{
Kira Markiewicz \\ Nancy L. Rose \\ Catherine Wolfram \\ Working Paper 11001 \\ http://www.nber.org/papers/w11001 \\ NATIONAL BUREAU OF ECONOMIC RESEARCH \\ 1050 Massachusetts Avenue \\ Cambridge, MA 02138 \\ December 2004
}

Rose gratefully acknowledges support from the MIT Center for Energy and Environmental Policy Research (CEEPR), the Hoover Institution, the Guggenheim Foundation, and the National Bureau of Economic Research. We thank participants at NBER Productivity and Industrial Organization program meetings, the University of California Energy Institute POWER conference, and the MIT CEEPR conference, as well as seminar participants at Chicago, Harvard, MIT, UC Berkeley, UC Davis and Yale for their suggestions. Our work has benefited greatly from detailed comments by Mitali Das, Al Klevorick, Mark Roberts, Charles Rossman and Johannes Van Biesebroeck, and two anonymous referees. We thank Tom Wilkening for assistance in coding restructuring policies across states and Jen-Jen L'ao for assistance coding plant identities. The views expressed herein are those of the author(s) and do not necessarily reflect the views of the National Bureau of Economic Research.

(C) 2004 by Kira Markiewicz, Nancy L. Rose, and Catherine Wolfram. All rights reserved. Short sections of text, not to exceed two paragraphs, may be quoted without explicit permission provided that full credit, including $\odot$ notice, is given to the source. 
Do Markets Reduce Costs? Assessing the Impact of Regulatory Restructuring on U.S. Electric

Generation Efficiency

Kira Markiewicz, Nancy L. Rose, and Catherine Wolfram

NBER Working Paper No. 11001

December 2004, Revised June 2007

JEL No. L11,L43,L51,L94,D24

\section{ABSTRACT}

While neoclassical models assume static cost-minimization by firms, agency models suggest that firms may not minimize costs in less-competitive or regulated environments. We test this using a transition from cost-of-service regulation to market-oriented environments for many U.S. electric generating plants. Our estimates of input demand suggest that publicly-owned plants, whose owners were largely insulated from these reforms, experienced the smallest efficiency gains, while investor-owned plants in states that restructured their wholesale electricity markets improved the most. The results suggest modest medium-term efficiency benefits from replacing regulated monopoly with a market-based industry structure.

Kira Markiewicz 1300 Clifton Road

Goizueta School of Business

Atlanta, GA

30322

Kira_Fabrizio@bus.emory.edu

Nancy L. Rose

Department of Economics

MIT, E52-280B

50 Memorial Drive

Cambridge, MA 02142-1347

and NBER

nrose@mit.edu
Catherine Wolfram

Haas School of Business

University of California, Berkeley

Berkeley, CA 94720-1900

and NBER

wolfram@haas.berkeley.edu 
Economists have long maintained that markets generate important efficiency benefits for an economy. These arguments usually focus on allocative efficiency; the implications of competition for technical efficiency are less clear. Neoclassical models of profit-maximization assume static cost-minimizing behavior by all firms, regardless of market competitiveness. ${ }^{1}$ Agency models, however, in recognizing the interplay of asymmetric information with the separation of management and control, suggest possible deviations from cost-minimization by effort-averse managers. These distortions may be amplified when a firm's prices are set by asymmetrically-informed regulators (e.g., JeanJacques Laffont and Jean Tirole, 1993). Replacing regulated price determination with markets makes firms residual claimants to cost-savings, potentially increasing incentives for efficiency-enhancing effort. ${ }^{2}$ Theory suggests several possible roles for markets: constraining managerial behavior by rewarding efficiency gains, confronting less-efficient firms with the choice of cost reduction to the level of their lower-cost counterparts or exit, and perhaps reducing agency costs. ${ }^{3}$ The actual relevance of markets for technical efficiency ultimately is an empirical question.

This paper uses data on the U.S. electric generation sector to assess the effect on technical efficiency of shifting regulated monopolies to more market-based environments. The past decade has witnessed a dramatic transformation of this industry. Until the mid1990s, over ninety percent of the electricity in the US was sold by vertically-integrated

\footnotetext{
${ }^{1}$ The implication of competition for dynamic efficiency through innovation is the subject of an extensive theoretical and empirical literature in economics, dating at least from Joseph Schumpeter's 1942 classic Capitalism, Socialism, and Democracy.

${ }^{2}$ In contrast, Xavier Vives (2006) develops a model in which deregulation may lead to increased competitive pressure and reduced R\&D investment, leading to a negative effect on cost-reducing innovation.
} 
investor-owned utilities (IOUs), most operating as regulated monopolists within their service areas. Many utilities faced some form of incentive-based regulation, adopted by states during the 1980s and early 1990s to improve upon the efficiency incentives of traditional cost-of-service regulation. More radical reform was initiated in the mid-1990s, as many states began to restructure their electric utility markets. Today, nonutility generators own roughly a quarter of generation capacity nationwide, and IOUs in many states own only a small fraction of total generating capacity and operate in a structure that relies heavily on market-based incentives. While studies of state-level electricity restructuring suggest that politicians may have been motivated in large part by rentseeking (e.g., Matthew W. White, 1996, and Paul L. Joskow, 1997), many proponents of restructuring argued that exposing utilities to competitive, market-based outcomes would yield efficiency gains that could ultimately reduce electricity costs and retail prices.

The considerable body of empirical research on electricity restructuring within the U.S. and abroad has thus far focused on assessing the performance of competitive wholesale markets, with particular attention to the exercise of market power (e.g., Severin Borenstein, James Bushnell and Frank A. Wolak, 2002 and Joskow and Edward Kahn, 2002, and Wolak, forthcoming). While many of the costs of electricity restructuring have been intensively studied, relatively little effort has been devoted to quantifying any ex post operating efficiency gains of restructuring. Christopher R. Knittel (2002) reports evidence of some electric generating plant efficiency increases associated with the diffusion of incentive regulation. ${ }^{4}$ The question of whether further reform-moving from

\footnotetext{
${ }^{3}$ Stephen J. Nickell (1996) provides a discussion of many of these theoretical arguments. Jen Baggs and Jean-Etienne de Bettignies (forthcoming) develop a model in which competition may reduce costs through both direct effects, such as those described in Nickell (1996), and reductions in agency costs.

${ }^{4}$ Incentive regulations have been more extensively studied in the telecommunications sector; e.g., Chunrong Ai and David Sappington (2002), or Donald Kridel, Sappington, and Dennis Weisman (1996) for a survey of many such studies.
} 
incentive-based regulation to deregulated markets for generation-yields additional improvements in plant efficiency remains open.

Research on other industries suggests productivity gains associated with deregulation (e.g., G. Steven Olley and Ariel Pakes, 1996, on telecommunications and Charles K. Ng and Paul Seabright, 2001, on airlines) and with increased competitive pressure caused by factors other than regulatory change (e.g., José E. Galdón-Sánchez and James A. Schmitz, Jr., 2002, on iron ore mines). ${ }^{5}$ This study provides the first substantial analysis of early generation efficiency gains from electricity restructuring. ${ }^{6}$ As such, it is of direct policy relevance to states contemplating the future of their electricity restructuring programs, and contributes to the broad economic debate on the role of competition in the economy.

The results of our work indicate that the plant operators most affected by restructuring reduced labor and nonfuel expenses, holding output constant, by three to five percent relative to other investor-owned utility plants, and by six to twelve percent relative to government- and cooperatively-owned plants that were largely insulated from restructuring incentives. These may be interpreted as the medium-run efficiency gains that Joskow (1997, p. 214) posits "may be associated with improving the operating

\footnotetext{
${ }^{5}$ Some hint of this possibility in electricity is provided by Walter J. Primeaux (1977), who compared a sample of municipally owned firms facing competition to a matched sample of municipally owned firms in monopoly situations and found a significant decrease in costs per $\mathrm{kWh}$ for firms facing competition. ${ }^{6}$ Joskow (1997) describes the significant labor force reductions that accompanied restructuring in the UK, as the industry moved from state-owned monopoly to a privatized, competitive generation market, although these mix restructuring and privatization effects. The only econometric evidence on restructuring of which we are aware is from L. Dean Hiebert (2002), who uses stochastic frontier production functions to estimate generation plant efficiency over 1988-1997, treating all inputs as orthogonal to productivity shocks. Hiebert models plant inefficiency as a function of several variables, including indicators for state regulatory or legislative enactment of utility restructuring in 1996 and in 1997 . He reports a huge reduction in estimated mean inefficiency for coal plants in states deemed to have restructured in 1996 but none for gas plants in those states, and no effect on plants of either fuel type for policies enacted in 1997. Our work uses a longer time period, richer characterization of the restructuring environment and dating of reforms consistent with the U.S. Energy Information Administration, and an alternative technology specification that both allows for more complex productivity shocks and treats possible input endogeneity biases.
} 
performance of the existing stock of generating facilities and increasing the productivity of labor operating these facilities." Our work also highlights the importance of treating the simultaneity of input and output choice. Failing to recognize that shocks to input productivity may induce firms to adjust targeted output leads to overstatement of estimated efficiency effects, by nearly a factor of two in some cases. While endogeneity concerns have been long recognized in the productivity literature, ours is one of the first studies of electric generation to control for this. Finally, we explore the sensitivity of the estimated efficiency impact to the choice of control group to which restructured plants are compared, and discuss the issues involved in determining the appropriate counterfactual.

The remainder of the paper is organized as follows: Section I describes existing evidence on the competitive effects of efficiency and discusses how restructuring might alter electric generation efficiency. Section II details our empirical methodology for testing these predictions and describes our strategy for identifying restructuring effects. The data are described in Section III. Section IV reports the results of the empirical analysis, and Section V concludes.

\section{Why Might Restructuring Affect Generator Efficiency?}

Through the early 1990s, the U.S. electricity industry was dominated by vertically integrated investor-owned utilities. Most operated as regulated monopolists over generation, transmission, and distribution of electricity within their localized geographic market, though there was some wholesale power traded among utilities or purchased from a small but growing number of nonutility generators. Prices generally were determined by state regulators based on accounting costs of service at the firm level. It has long been argued that traditional cost-of-service regulation does relatively well in limiting rents but less well in providing incentives for cost-minimizing production (e.g., Laffont and Tirole, 
1993). Under pure cost-of-service regulation, regulator-approved costs are passed directly through to customers, and reductions in the cost of service yield at most short-term profits until rates are revised to reflect the new lower costs at the next rate case. ${ }^{7}$ Given asymmetric information between regulators and firms, inefficient behavior by managers that raises operating costs above minimum cost levels generally would be reflected in increased rates and passed through to customers. Joskow (1974) and Wallace E. Hendricks (1975) demonstrate that frictions in cost-of-service regulation, particularly those arising from regulatory lag (time between price-resetting hearings), may provide some incentives at the margin for cost-reducing effort. Their impact generally is limited, however, apart from periods of rapid nominal cost inflation (Joskow, 1974).

This system led economists to argue that replacing cost-of-service regulation with higher-powered regulatory incentive schemes or increased competition could enhance efficiency. ${ }^{8}$ Over the 1980 s and early 1990 s, many state utility commissions accordingly adopted some form of incentive regulation. The little empirical evidence available on these reforms, which modify price setting within the regulated monopoly structure, suggests limited effects. Knittel (2002) studies a variety of incentive regulations in use through 1996, and finds that those targeted at plant performance or fuel cost were associated with gains in plant-level generation efficiency. ${ }^{9}$ More general reforms, such as price caps, rate freezes, and revenue-decoupling programs, typically were associated with insignificant or negative efficiency estimates, all else equal.

\footnotetext{
${ }^{7}$ Rates are constant between rate cases, apart from specific automatic adjustments (such as fuel adjustment clauses), so changes in cost would not be reflected in rates until the next rate case.

${ }^{8}$ See, for example, Laffont and Tirole (1993), for a theoretical justification, or Joskow and Richard Schmalensee (1987), for an applied argument.

${ }^{9}$ Knittel uses OLS and stochastic production frontier techniques to estimate Cobb-Douglas generating plant production functions in capital, labor, and fuel for a panel of large IOU plants over 1981-1996. His results from first-differenced models, which implicitly allow for fixed plant-level efficiency effects, suggest gains
} 
During the second half of the 1990s, states began to shift their focus from incentive regulation to restructuring. By 1998, every jurisdiction (50 states and the District of Columbia) had initiated formal hearings to consider restructuring their electricity sector, and by 2000, almost half had approved legislation introducing some form of competition that included competitive retail access, whereby companies competed to sell power to retail customers. ${ }^{10}$ Restructuring initiatives, in contrast to incentive regulations, fundamentally changed the way plant owners earn revenue. At the wholesale level, plants sell either through newly created spot markets or through long-term contracts that are presumably based on expected spot prices. In the spot markets, plant owners submit bids indicating the prices at which they are willing to supply power from their plants. Dispatch order is set by the bids, and, in most markets, the bid of the marginal plant is paid to all plants that are dispatched. High-cost plants will be forced down in the dispatch order, reducing expected revenue. ${ }^{11}$ Plant operators that reduce costs can move higher in the dispatch order to increase dispatch probability, and increase the profit margin between own costs and the expected market price. Most restructuring programs also changed the way retail rates are determined and the way in which retail customers are allocated. $^{12}$ Retail access programs in combination with the creation of the new wholesale spot markets may increase the intensity of cost-cutting incentives, leading to even greater effort to improve efficiency.

\footnotetext{
on the order of 1-2 percent associated with these reforms. Equations that do not allow for plant fixed effects suggest much larger magnitudes.

${ }^{10}$ In the aftermath of California's electricity crisis in 2000-2001, restructuring has become less popular and many states have delayed or suspended restructuring activity, including six that had previously approved retail access legislation. See US Energy Information Administration (EIA), 2003.

${ }^{11}$ This could induce closure. We address potential selection-induced biases from exit below.

${ }^{12}$ States have used a variety of approaches to link retail rates under restructuring to wholesale prices in the market. Over the short term, most states decoupled utility revenue from costs by mandating retail rate freezes, often at levels discounted from pre-restructuring prices. Some states, such as Pennsylvania, are aggressively trying to encourage entry by competitive energy suppliers, who may contract directly with retail customers.
} 
Exit by less-efficient firms is a well-understood efficiency benefit of competition: as output shifts from (innately) higher-cost firms to lower-cost competitors the total production cost for a given output level declines. Olley and Pakes (1996) provide empirical evidence of this phenomenon in their plant-level analysis of the magnitude and source of productivity gains in the U.S. telecommunications equipment industry over 1974-1987. They find substantial increases in productivity associated with the increased competition that followed the 1984 divestiture and deregulation in this sector, and identify the primary source of these gains as the re-allocation of output from less productive to more productive plants across firms. In a similar vein, Chad Syverson (2004) finds that more competitive local markets in the concrete industry are associated with higher mean, less dispersion, and higher lower-bounds in plant productivity, effects he attributes to the exit of less-efficient plants in more competitive environments.

The existing evidence on whether competition also leads to cost reductions through technical efficiency gains by continuing producers and plants is relatively sparse. Nickell (1996) uses a panel of 670 U.K. manufacturing firms to estimate production functions that include controls for the competitive environments in which firms operate. He finds some evidence of reduced productivity levels associated with market power and strong support for higher productivity growth rates in more competitive environments. Concerns about the ability of cross-industry analysis to control adequately for unobservable heterogeneity across sectors may make sector-specific evidence tighter and more convincing. ${ }^{13}$ A notable example is the Galdón-Sánchez and Schmitz (2002) study of labor productivity gains at iron ore mines that faced increased competitive pressure

\footnotetext{
${ }^{13}$ A number of studies have analyzed efficiency gains following regulatory reform in various industries; see, for example, Elizabeth E. Bailey (1986) and B.U. Park et al. (1998) on airlines. Unfortunately, in many cases it is difficult to disentangle direct regulatory effects on efficiency (e.g., operating restrictions imposed on trucking firms or airlines by regulators in those sectors) from the indirect effects of reduced competition.
} 
following the collapse of world steel production in the early 1980s. They find unprecedented rates of labor productivity gains associated with this increase in competitive pressure, “driven by continuing mines, producing the same products and using the same technology as they had before the 1980 s" (at 1233). ${ }^{14}$

Several features of the electric generation sector make it an attractive subject for testing these potential competitive effects on technical efficiency. ${ }^{15}$ First, generation technology is reasonably stable and well-understood and data on production inputs and outputs at the plant-level are readily available to researchers. This has made electric generation a common application for new production and cost function estimation techniques, dating at least from Marc Nerlove (1963). Second, policy shifts over a relatively short period have resulted in a dramatic transformation of the market for electric power. This provides both time series and geographic variation in competitive environments. Finally, static and dynamic efficiency claims bolstered much of the policy reform; measuring these benefits is a vital prerequisite to assessing the wisdom of these policies.

While the most significant savings from restructuring are likely to be associated with efficient long-run investments in new capacity, there may be opportunities for modest reductions in operating costs of existing plants (Joskow, 1997). This paper attempts to measure the extent of that possible improvement for the existing stock of electricity generating plants in the U.S. The implicit null hypothesis is that before restructuring, operators were minimizing their costs given the capital stock available in the

\footnotetext{
${ }^{14} \mathrm{Ng}$ and Seabright (2001) estimate cost functions for a panel of U.S. and European airlines over 19821995 , and conclude that potential gains from further privatization and increased competition among European carriers are substantial, though they point out that the best-measured component of these gains relates to ownership rather than market structure differences.

${ }^{15}$ Understanding possible reallocation of output across plants is hampered by the exit of plants from most publicly available databases when they are sold to nonutility owners.
} 
industry. Under the null, there should be no change in plant-level efficiency measures associated with restructuring activity. We discuss below our method for estimating plant efficiency and identifying deviations from this hypothesis. To assess the effects of restructuring, we need to specify how generating plants would have operated absent the policy change. Constructing this counterfactual is crucial, but difficult.

\section{Empirical Model}

For a single-output production process, productive efficiency can be assessed by estimating whether a plant is maximizing output given its inputs and whether it is using the best mix of inputs given their relative prices. Production functions describe the technological process of transforming inputs to outputs and ignore the costs of the inputs; a plant is efficient if it is on the production frontier. Cost minimization assumes that, given the input costs, firms choose the mix of inputs that minimizes the costs of producing a given level of output. A plant could be producing the most output possible from a given input combination but not minimizing costs if, for instance, labor were cheap relative to materials, yet the plant used a lot of materials relative to labor. Even if the plant were producing the maximum output possible from its workers and materials, it would not be efficient if it could produce the same level of output less expensively by substituting labor for materials. We explore the impact of restructuring on efficiency by specifying a production function and then deriving the relevant input demand equations implied by cost minimization.

We adopt the convention of representing electric generating plant output (Q) by the net energy the generating units produce over some period. This is measured by annual megawatt-hours, MWh, in our data, as discussed in further detail in the data section below. While many studies of generating plant productivity model this output as a 
function of current inputs using a Cobb-Douglas production function, the characteristics of electricity production argue strongly for an alternative specification. We derive a model of production and cost minimization that is sensitive to important institutional characteristics of electricity production that have been ignored in much of the earlier literature.

First, observed output in general will be the lesser of the output the plant is prepared to produce given its available inputs (we call this probable output), and the output called for by the system dispatcher (we call this actual output). Because the system dispatcher must balance total production with demand at each moment, the gap between probable $\left(\mathrm{Q}^{\mathrm{P}}\right)$ and actual $\left(\mathrm{Q}^{\mathrm{A}}\right)$ output for a given plant $i$ will be a function of demand realizations, the set of other plants available for dispatch, and plant $i$ 's position in the dispatch order. $^{16}$

Second, while fuel inputs are varied in response to real-time dispatching and operational changes, other inputs to a plant's production are determined in advance of output realizations. Capital typically is chosen at the time of a unit's construction (or retirement), and at the plant level large capital changes are relatively infrequent. From the manager's perspective, it may be considered a fixed input. Utilities hire labor and set operating and materials expenditures in advance, based on expected demand. While these can be adjusted over the medium-run, staffing decisions as well as most maintenance expenditures are not tied to short-run fluctuations in output. ${ }^{17}$ We therefore treat these as set in advance of actual production, and determining a target level of probable output, $\mathrm{Q}^{\mathrm{P}}$.

\footnotetext{
${ }^{16}$ Random shocks to a plant's operations, such as unexpected equipment failures or equipment that lasts longer than expected, will cause it to produce less or more than its probable output from a set of available inputs.

${ }^{17}$ In fact, over a short time period, maintenance and repair expenditures will be inversely related to output since the boiler needs to be cool and the plant offline for most major work. We deal with this potential simultaneity bias below.
} 
Finally, while labor, materials, and capital may be to some extent substitutable to produce probable output, the generation process generally does not allow these inputs to substitute for fuel in the short-run. Given this description of the technology, we posit a Leontief production process for plant $i$ in year $t$ of the following form:

$$
\mathrm{Q}_{\mathrm{it}}^{\mathrm{A}}=\min \left[\mathrm{g}\left(\mathrm{E}_{\mathrm{it}}, \Gamma^{\mathrm{E}}, \varepsilon_{\mathrm{it}}^{\mathrm{E}}\right), \mathrm{Q}_{\mathrm{it}}^{\mathrm{P}}\left(\mathrm{K}_{\mathrm{i}}, \mathrm{L}_{\mathrm{it}}, \mathrm{M}_{\mathrm{it}}, \Gamma^{\mathrm{P}}, \varepsilon_{\mathrm{it}}^{\mathrm{P}}\right) \cdot \exp \left(\varepsilon_{\mathrm{it}}^{\mathrm{A}}\right)\right]
$$

where $\mathrm{Q}^{\mathrm{A}}$ is actual output and $\mathrm{Q}^{\mathrm{P}}$ is probable output; inputs are denoted by $\mathrm{E}$ for energy (fuel) input, $\mathrm{K}$ for capital, $\mathrm{L}$ for labor, and $\mathrm{M}$ for materials; $\Gamma$ denotes parameter vectors, and $\varepsilon$ denotes unobserved (to the econometrician) mean zero shocks. See Johannes Van Biesebroeck (2003) for the derivation of a similar production function he uses to model automobile assembly plant production.

As noted above, fuel input decisions are made in real time, after the manager has observed any shocks associated with the plant's probable output productivity, $\varepsilon_{\mathrm{it}}{ }^{\mathrm{P}}$, the actual operation of the plant, $\varepsilon_{i t}{ }^{\mathrm{A}}$, and the plant's energy-specific productivity in the current period, $\varepsilon_{\mathrm{it}}{ }^{\mathrm{E}}$. Probable output, $\mathrm{Q}^{\mathrm{P}}$, is in contrast determined by input decisions made in advance of actual production. We assume that capital, measured by the nameplate generating capacity of the plant, is fixed. ${ }^{18}$ Labor and materials decisions are made in advance of production, but after the level and productivity of the plant's capital is observed. This reflects the quasi-fixity of these inputs over time: staffing decisions and maintenance plans are designed to ensure that the plant is available when it is dispatched, based on the targeted output $Q^{P}$. The error term $\varepsilon_{i t}{ }^{P}$ incorporates productivity shocks that we assume are known to the plant manager in advance of scheduling labor and materials inputs, but are not observable to the econometrician. We allow actual output to differ from probable output by a multiplicative shock $\exp \left(\varepsilon_{\mathrm{it}}{ }^{\mathrm{A}}\right)$, assumed to be observed at the 
time fuel input choices are made but not known at the time probable output is determined. This shock would be, for example, negative if a generating unit were unexpectedly shut down due to a mechanical failure, or positive if the plant were run more intensively than anticipated, as might be the case if a number of plants ahead of it in the usual dispatch order were unavailable or demand realizations were unexpectedly high.

We model probable output $\left(\mathrm{Q}^{\mathrm{P}}\right)$ as a Cobb-Douglas function of labor and materials, embedding capital effects in a constant $\left(\mathrm{Q}_{0}(\mathrm{~K})\right)$ term. This yields the specification:

$$
\mathrm{Q}_{\text {it }}{ }^{\mathrm{P}} \leq \mathrm{Q}_{0}\left(\mathrm{~K}_{\mathrm{i}}\right) \cdot\left(\mathrm{L}_{\mathrm{it}}\right)^{\gamma \mathrm{L}} \cdot\left(\mathrm{M}_{\mathrm{it}}\right)^{\gamma \mathrm{M}} \cdot \exp \left(\varepsilon_{\mathrm{it}}{ }^{\mathrm{P}}\right)
$$

In preliminary analysis, we estimated the parameters of the production function, including terms that allowed for differential productivity under restructuring. Those results suggested productivity gains associated with restructuring. The work reported here imposes an additional constraint, based on cost-minimization, to estimate input demand functions, and isolate possible restructuring effects on each measured input. A costminimizing plant manager, facing wages $\mathrm{W}_{\text {it }}$ and material prices $\mathrm{S}_{\mathrm{it}}$, would solve for the optimal inputs to produce probable output $\underline{Q}_{i t}{ }^{\mathrm{P}}$ by:

$$
\begin{aligned}
& \min \mathrm{W}_{\mathrm{it}} \cdot \mathrm{L}_{\mathrm{it}}+\mathrm{S}_{\mathrm{it}} \cdot \mathrm{M}_{\mathrm{it}} \quad \text { s.t. } \underline{\mathrm{Q}}_{\mathrm{it}}{ }^{\mathrm{P}} \leq \mathrm{Q}_{0}\left(\mathrm{~K}_{\mathrm{i}}\right) \cdot\left(\mathrm{L}_{\mathrm{it}}\right)^{\gamma \mathrm{L}} \cdot\left(\mathrm{M}_{\mathrm{it}}\right)^{\gamma \mathrm{M}} \cdot \exp \left(\varepsilon_{\mathrm{it}}{ }^{\mathrm{P}}\right) \\
& \mathrm{L}_{\mathrm{it}}, \mathrm{M}_{\mathrm{it}}
\end{aligned}
$$

yielding the following factor demand equations:

$$
\begin{aligned}
& \mathrm{L}_{\mathrm{it}}=\left(\lambda \gamma^{\mathrm{L}} \mathrm{Q}_{\mathrm{it}}^{\mathrm{P}}\right) / \mathrm{W}_{\mathrm{it}} \\
& \mathrm{M}_{\mathrm{it}}=\left(\lambda \gamma^{\mathrm{M}} \mathrm{Q}_{\mathrm{it}}{ }^{\mathrm{P}}\right) / \mathrm{S}_{\mathrm{it}}
\end{aligned}
$$

where $\lambda$ is the Lagrangian on the production constraint.

\footnotetext{
${ }^{18}$ The empirical analysis defines a new plant-epoch, $i$, whenever there are significant changes in capacity, so that within each plant-epoch, capacity is approximately constant.
} 
We observe actual output, $\mathrm{Q}_{\mathrm{it}}{ }^{\mathrm{A}}=\mathrm{Q}_{\mathrm{it}}{ }^{\mathrm{P}} \exp \left(\varepsilon_{\mathrm{it}}{ }^{\mathrm{A}}\right)$, rather than probable output, $\mathrm{Q}_{\mathrm{it}}{ }^{\mathrm{P}}$.

Making this substitution and taking logs of both sides, equation (2) becomes:

$$
\ln \left(\mathrm{L}_{\mathrm{it}}\right)=\alpha_{0}+\ln \left(\mathrm{Q}_{\mathrm{it}}{ }^{\mathrm{A}}\right)-\varepsilon_{\mathrm{it}}{ }^{\mathrm{A}}-\ln \left(\mathrm{W}_{\mathrm{it}}\right)
$$

where $\alpha_{0}=\ln \left(\lambda \gamma^{\mathrm{L}}\right)$. If there are differences across plants, over time, or across regulatory regimes in the coefficients of the production function $\left(\gamma^{\mathrm{L}}\right)$ or in the shadow value of the probable output constraint $(\lambda)$, or if there is measurement error in labor used at the plant, this equation will hold with error. As we are particularly interested in changes in input demand associated with restructuring, we expand the subscript it to irt to include plant $i$ in year $t$, and regulatory restructuring regime $r$, and re-write equation (6) as: ${ }^{19}$

$$
\ln \left(\mathrm{L}_{\text {irt }}\right)=\ln \left(\mathrm{Q}_{\text {irt }}{ }^{\mathrm{A}}\right)-\ln \left(\mathrm{W}_{\text {irt }}\right)+\alpha_{\mathrm{i}}^{\mathrm{L}}+\delta_{\mathrm{t}}^{\mathrm{L}}+\varphi_{\mathrm{r}}^{\mathrm{L}}-\varepsilon_{\text {irt }}{ }^{\mathrm{A}}+\varepsilon_{\text {irt }}^{\mathrm{L}}
$$

where $\alpha_{i}^{\mathrm{L}}$ measures a plant-specific component of labor demand, $\delta_{t}^{\mathrm{L}}$ captures year-specific differences in labor demand, $\varphi_{\mathrm{r}}{ }^{\mathrm{L}}$ captures restructuring-specific shifts in labor demand, and $\varepsilon_{\text {irt }}^{\mathrm{L}}$ measures the remaining error in the labor input equation. $\alpha_{0}$ is now subsumed in the plant-specific demand, $\alpha_{i}^{\mathrm{L}}$. Note that $\varphi_{\mathrm{r}}{ }^{\mathrm{L}}$ picks up mean residual changes in labor input for a plant in a restructured regime relative to that plant overall and to all other plants at the same point in time. It could reflect systematic changes in the marginal productivity of labor $\left(\gamma^{\mathrm{L}}\right)$, in the shadow value of the availability constraint $(\lambda)$ or in optimization errors. $^{20}$

Similarly, equation (5) becomes:

$$
\ln \left(\mathrm{M}_{\mathrm{irt}}\right)=\ln \left(\mathrm{Q}_{\mathrm{rt}}^{\mathrm{A}}\right)-\ln \left(\mathrm{S}_{\mathrm{rt}}\right)+\alpha_{\mathrm{i}}^{\mathrm{M}}+\delta_{\mathrm{t}}^{\mathrm{M}}+\varphi_{\mathrm{r}}^{\mathrm{M}}-\varepsilon_{\mathrm{irt}}{ }^{\mathrm{A}}+\varepsilon_{\mathrm{irt}}^{\mathrm{M}}
$$

which is directly analogous to equation (7).

\footnotetext{
${ }^{19}$ Note that many plant-level differences, such as capital stock, and many time-varying shocks, such as technology-neutral productivity shocks, drop out of this equation when we condition on output choice.

${ }^{20}$ If there are systematic differences in the relation of probable and actual output across restructuring, $\gamma_{\mathrm{r}}{ }^{\mathrm{L}}$ may also reflect the change in mean $\varepsilon_{\text {irt }}{ }^{\mathrm{A}}$. Since $\varepsilon_{\text {irt }}{ }^{\mathrm{A}}$ reflects shocks unobservable by the firm when setting planned output, it seems plausible that these could be mean zero in expectation, but their realizations could be nonzero in the restructuring sample we observe.
} 
We model the energy component of the Leontief production function, which will in general hold with equality, as:

$$
\mathrm{Q}_{\text {irt }}^{\mathrm{A}}=\mathrm{g}\left(\mathrm{E}_{\text {irt }}, \gamma^{\mathrm{E}}, \varepsilon^{\mathrm{E}}\right)
$$

Assuming that $\mathrm{g}(\bullet)$ is monotonically increasing in E, we can simply invert it to get an expression for $\mathrm{E}$ in terms of $\mathrm{Q}$. Note that the price of fuel does not enter into the demand for fuel except through the level of output the plant is dispatched to produce. For consistency with the other input specifications, we specify a log-log relationship:

$$
\ln \left(\mathrm{E}_{\mathrm{irt}}\right)=\gamma_{\mathrm{Q}}^{\mathrm{E}} \cdot \ln \left(\mathrm{Q}_{\mathrm{irt}}\right)+\varphi_{\mathrm{r}}^{\mathrm{E}}+\alpha_{\mathrm{i}}^{\mathrm{E}}+\delta_{\mathrm{t}}^{\mathrm{E}}+\varepsilon_{\mathrm{irt}}^{\mathrm{E}}
$$

where as before, the plant-specific error, $\alpha_{i}{ }^{E}$, the year-specific error, $\delta_{t}{ }_{t}^{E}$, and the restructuring-specific term, $\varphi_{\mathrm{r}}{ }^{\mathrm{E}}$, capture systematic changes in the efficiency with which plants convert energy to electricity - that is, changes in plant heat rates - across plants, over time, or correlated with restructuring activity, respectively.

We confront two important endogeneity concerns in estimating the basic input demand equations, (7), (8) and (10). The first is the possibility that shocks $\left(\varepsilon_{\text {irt }}^{\mathrm{L}}, \varepsilon_{\text {irt }}^{\mathrm{M}}\right.$, $\left.\varepsilon_{\text {irt }}^{\mathrm{E}}\right)$ in the input demand equations may be correlated with output. If output decisions are made after a plant's manager observes the plant's efficiency, managers may increase planned output in response to positive shocks to an input's productivity, or reduce planned output in response to negative shocks. This behavior would induce a correlation between the error in the input demand equation and observed output. Though one can control directly for plant-specific efficiency differences and for secular productivity shocks in a given year, idiosyncratic shocks remain a source of possible bias. Second, the estimates may be subject to selection bias if exit decisions are driven by unobserved productivity shocks. In this case, negative shocks could lead to plant shutdown, implying that the errors for observations we observe will be drawn from a truncated distribution. Neither of 
these problems is unique to our setting, and they have been raised in many earlier papers. $^{21}$

Consider first the simultaneity issue. We face a potential simultaneity problem if, for instance, a malfunctioning piece of equipment reduces the plant's fuel efficiency, leading the utility to reduce its operation of that plant and consequently to use less fuel. There may be deviations from predetermined employment and materials budgets caused by unanticipated breakdowns that require increased use of labor and repair expenditures and result in lower output. A variety of methods have been used to address concerns about simultaneity. ${ }^{22}$ We choose to use an instrumental variables approach, using a measure of state-level electricity demand as an instrument for plant output. Geographic electric generation markets are likely to be at least as broad as the state-level at the annual frequency of our data. This demand is likely to be highly correlated with the amount of output a plant will be called to provide, but uncorrelated, for instance, with how efficiently an individual plant's feedwater pumps are working. This approach is likely to be particularly effective for the energy equation, given the responsiveness of energy input choices to demand fluctuations in real time, and for identifying exogenous output fluctuations at nonbaseload plants, which are more strongly influenced by marginal swings in demand. It may be less powerful in identifying variation in ex ante labor and maintenance choices, depending in part on the extent to which plant managers anticipate state demand. We have explored the sensitivity of our results to a broad set of alternative

\footnotetext{
${ }^{21}$ Nerlove (1963) provides an early discussion of simultaneity bias in production functions. Olley and Pakes (1996) propose a structural approach to addressing simultaneity, which is compared to alternatives in Zvi Griliches and Jacques Mairesse (1998). Daniel A. Ackerberg et al. (2005) discuss this issue and compare treatments proposed by Olley and Pakes (1996) and James Levinsohn and Amil Petrin (2003). While many papers have estimated production or cost functions for electric generating plants, from the classic analyses in Nerlove (1963) and Laurits R. Christensen and William H. Greene (1976) to very recent work such as Andrew N. Kleit and Dek Terrell (2001) and Knittel (2002), electricity industry studies typically have not treated either simultaneity or selection problems.
} 
instruments, including interactions of state demand with relative plant efficiency (heatrates), fuel type, and load profile that allow for plant-level variation in the instrument set, weather-related demand drivers (cooling and heating degree days), and lags in plantlevel output (similar to Richard Blundell and Stephen Bond, 1998 and 2000). ${ }^{23}$ The results reported below are qualitatively robust to these alternatives.

The potential selection issue is more difficult to address. The plants in our sample are more stable than those studied in many other contexts (especially see Olley and Pakes, 1996), suggesting that the selection problem may be somewhat less severe for electric generation. Exit in our sample is relatively rare, apart from exit induced when restructuring-related divestitures remove the plant from the reporting database. Adverse productivity shocks are much more likely to result in reduced run time than in plant retirements for the large generating plants analyzed in this work. To the extent that the divestitures were mandated by restructuring policies, these also should not create selection problems. In all states where plant divestitures were part of the restructuring process except New York, virtually all of the utility-owned fossil-fuel fired plants were divested, suggesting that the extent and incidence of divestitures following restructuring are largely nondiscretionary. ${ }^{24}$ To further gauge the significance of potential selection effects, we have compared results for the unbalanced panel we use in the analysis to those for a panel of plants that continue to operate through the end of our sample period, for which potential selection effects are likely to be most severe. With one exception, the results from the

\footnotetext{
22 See the references cited in note 21 , supra.

${ }^{23}$ This is discussed in detail in a Technical Appendix to this paper, available on the American Economic Review website and as an appendix to Kira Fabrizio, et al. (hereafter FRW ), 2007. The Technical Appendix discusses these and other robustness checks.

${ }^{24}$ See the analysis in James B. Bushnell and Catherine D. Wolfram (2005) and the discussion in FRW (2007) Technical Appendix.
} 
balanced panel are similar to the main results reported in this paper, suggesting there is little to be gained from a more detailed treatment of potential selection biases. ${ }^{25}$

\section{Identification strategy}

There is substantial spatial and temporal heterogeneity in the economic environment in which electric utilities have operated. There are thousands of generating plants operated by hundreds of utilities subject to regulation by dozens of political jurisdictions each setting their own legal and institutional environment. Restructuring, however, is not randomly assigned across political jurisdictions — earlier work suggests that it is strongly correlated with higher than average electricity prices in the crosssection. ${ }^{26}$ Fortunately, we have panel data on the costs and operations of most electric generating plants from well before any restructuring until the present. This allows us to construct benchmarks that we believe control for most of the potentially confounding variation.

The plant-specific effects, $\left\{\alpha_{i}^{\mathrm{N}}\right\}$, measure the mean use of input $N$ at plant $i$ relative to other plants in the sample. These effects may be associated with differences in plant technology type and vintage, ownership (government v. private utilities), and timeinvariant state effects. The year-specific shock, $\left\{\delta_{\mathrm{t}}{ }^{\mathrm{N}}\right\}$, measures the efficiency impact of sector-level shifts over time, such as secular technology trends, macroeconomic fluctuations or energy price shocks. Restructuring effects on plant productivity

\footnotetext{
${ }^{25}$ The exception is the coefficient on an indicator for transition to RETAIL ACCESS competition. This coefficient is smaller and statistically indistinguishable from zero in the balanced panel estimation of the NONFUEL EXPENSE regression. This could be due to the fact that several of the states that implemented retail access competition within our sample required generating plant divestitures. Divested plants generally are exempt from publicly disclosing the data that we rely on in our analysis, eliminating them from the balanced sample. The negative coefficient on RETAIL ACCESS in the full sample could reflect reduced spending on NONFUEL EXPENSES by plants that are eventually divested, though there are too few observations on divested plants to conclude this with any certainty.

${ }^{26}$ The significant role of sunk capital costs in regulatory ratemaking means that high prices do not necessarily imply high operating costs for generation facilities within a state, however. See Joskow (1997) for a discussion of the contributors to price variation across states.
} 
correspond to a nonzero $\left\{\varphi_{\mathrm{r}}{ }^{\mathrm{N}}\right\}$. Heterogeneity in the timing and outcomes of state-level restructuring activity allow the data to distinguish between temporal shocks and restructuring effects. While all states held hearings on possible restructuring, the earliest was initiated in 1993 and the latest in 1998. There is considerable variation in the outcome of those hearings, as well, with just under half the jurisdictions (23 states and the District of Columbia) enacting restructuring legislation between 1996 and $2000{ }^{27}$ The remainder considered and rejected, or considered and simply did not act on, such legislation. This variation allows us to use changes in efficiency at plants in states that did not pass restructuring legislation to identify restructuring separately from secular changes in efficiency of generation plants over time.

It is possible that plants in this control group also altered their behavior over the post-1992 period. This could be due to the introduction or intensification of incentive regulation within states that did not enact restructuring, to the expectation of potential restructuring that did not occur, or to spillovers from restructuring movements in other states (e.g. if regulators updated their information about the costs necessary to run plants of a certain type, or multi-state utilities operating under differing regimes improved efficiency of all their plants, not just those in restructuring states). To the extent this occurs, our comparison will understate the magnitude of any efficiency effect of restructuring.

We therefore consider a second control group, consisting of cooperatively-owned and publicly-owned municipal and federal plants, which for convenience we will refer to collectively as municipal or "MUNI" plants, although the group is broader than strictly

\footnotetext{
${ }^{27}$ We collected information on state restructuring legislation from various Energy Information Administration and National Association of Regulatory Utility Commissioners publications and state public utility commission websites. Since 2000 , no additional states have enacted restructuring legislation, and several have delayed or suspended restructuring activity in response to the California crisis.
} 
implied by this label. An extensive literature has debated the relative efficiencies of private and public ownership in this sector under traditional regulation, with quite mixed results. We abstract from this by allowing for plant-specific effects that absorb any levels differences in input use across ownership type. Restructuring generally altered the competitive environment only for private investor-owned utilities within a state, leaving those for publicly- and cooperatively-owned utilities unchanged. ${ }^{28}$ This suggests that MUNIs may provide a second benchmark against which to measure changes in efficiency associated with restructuring. To control for the possible divergence of publicly-owned plant input use in the years preceding the restructuring period, we allow a separate intercept shift for publicly-owned plants after 1987: MUNI*POST $1987 .{ }^{29}$ We then adopt a parameterization that measures $\left\{\varphi_{\mathrm{r}}{ }^{\mathrm{N}}\right\}$ relative to incremental differences at publiclyowned plants during the period that investor-owned utilities are at risk of restructuring, defined as 1993 forward, through inclusion of an indicator for MUNI*POST 1992.

Using $N$ to denote input (labor, nonfuel expenses, or fuel), and PRICE $E^{N}$ to denote the relevant input price (none for the fuel equation), we have input use equation (11):

$$
\begin{aligned}
\ln \left(\mathrm{N}_{\mathrm{irt}}\right)= & \ln \left(Q_{\mathrm{irt}}^{\mathrm{A}}\right)-\ln \left(\text { PRICE }_{\text {irt }}^{N}\right)+\gamma_{87} \text { MUNI*POST1987 } 7_{i t}+ \\
& \gamma_{92} \text { MUNI*POST1992 }_{i t}+\alpha_{\mathrm{i}}^{\mathrm{N}}+\delta_{\mathrm{t}}^{\mathrm{N}}+\varphi_{\mathrm{r}}^{\mathrm{N}}-\varepsilon_{\mathrm{irt}}^{\mathrm{A}}+\varepsilon_{\mathrm{irt}}^{\mathrm{N}}
\end{aligned}
$$

Base differences in input use across each investor-, publicly-, or cooperativelyowned plant are embedded in the plant fixed effects, $\left\{\alpha_{i}^{N}\right\}$. All plants experience common annual changes in input use measured by the time effects, $\left\{\delta_{t}{ }^{N}\right\}$; publicly-owned plants may experience a differential mean shift from these effects following 1987.

\footnotetext{
${ }^{28}$ Arizona and Arkansas, which included government-owned utilities in restructuring programs, are the two exceptions.

${ }^{29}$ In Figures 1 and 2, we report nonparametric time paths for IOU and MUNI plant efficiency that suggest some divergence between the groups prior to the beginning of state restructuring. While the designation of 1988-1992 as a transition period before restructuring is somewhat arbitrary, it serves as a conservative
} 
Restructuring effects are measured by the difference-in-differences in two implicit "nontreatment groups" to which investor-owned plants in restructuring regimes may be compared: investor-owned plants in non-restructuring regimes over 1993-1999 (with the IOU restructuring effect measured by $\varphi_{\mathrm{r}}{ }^{\mathrm{N}}$ ), and MUNI plants over 1993-1999 (with the IOU restructuring effect measured by $\left.\varphi_{\mathrm{r}}{ }^{\mathrm{N}}-\gamma_{92}\right)$.

\section{Data \& Summary Statistics}

The analysis in this paper is based on annual plant-level data for large fossil-fueled generating plants owned by U.S. electric utilities. Plants are comprised of at least one, but typically several, generating units, which may be added to or retired from service over the several-decade life of a generating plant. While an ideal dataset would allow us to explore efficiency at the generating unit level, inputs other than fuel are not available at the generating unit level. Some inputs, such as employees, are not assignable to a unit as they are shared across units at the plant. ${ }^{30}$ We therefore use a plant-year as an observation.

The Federal Energy Regulatory Commission (FERC) collects data for investorowned utility plants annually in the FERC Form 1, and the EIA and Rural Utilities Service (RUS) collect similar data for municipally-owned plants and rural electric cooperatives, respectively. These data include operating statistics such as size of the plant, fuel usage, percentage ownership held by the operator and other owners, number of employees, capacity factor, operating expense, year built, and many other plant-level statistics. Our base dataset includes all large fossil-fuel steam and combined cycle gas turbine generating

${ }^{30}$ Some labor may be shared across multiple plants, though assigned to one particular plant in our data. This will induce measurement error, particularly in our plant employment variable. 
plants for which data were reported to FERC, EIA or RUS over the 1981 through 1999

period. ${ }^{31}$ Further details on data construction are provided in the data appendix.

We follow the literature in characterizing output by the total energy output of the

plant over the year, measured by annual net megawatt-hours of electricity generation, $N E T$

$M W H$. This is an imperfect choice. Output is, in reality, multidimensional, although most

dimensions are not recorded in the plant data. For example, generating plants may also

provide reliability services (such as spinning reserves, when the plant stands ready to

increase output at short notice), voltage support and frequency control. While the

production process varies considerably across these different outputs, only net generation

is well-measured in the data. ${ }^{32}$

More importantly, electricity output is not a homogenous product. The availability

of the plant may be an important modifier of output quality. Because electricity is not

storable, firms must decide how to balance the costs associated with taking their plant

down to do maintenance against the probability that a poorly maintained plant will fail

during peak demand hours. Changes in incentives associated with restructuring may have

altered firms' assessments of these tradeoffs, although the expected direction of the effects

is theoretically ambiguous. ${ }^{33}$ Hourly output prices and output from individual plants

might allow us to better assess this. Lacking such data, we rely on a single output

dimension, while acknowledging its limitations.

\footnotetext{
${ }^{31}$ One unfortunate consequence of restructuring is that available data on plants sold by utilities to nonutility generators are extremely limited after the sale, due to changed reporting requirements. This means that plants will be excluded from our dataset after such sales.

32 The inputs required to produce a given level of energy (MWh) from a specific plant also will depend on whether the plant runs continuously or intermittently and on its average capacity utilization. Starting a plant frequently and running it at low capacity utilization rates typically use more inputs (particularly fuel) per MWh generated than does running a plant continuously at its rated capacity.

${ }^{33}$ For instance, under traditional regulation, utilities may have faced strong political incentives to avoid blackouts or brownouts, leading to investment in greater capacity to increase reserve margins and in greater maintenance resources to increase plant reliability. On the other hand, competitive firms producing in
} 
We have information on three variable inputs. The first, EMPLOYEES, is a count of full-time equivalent employees at the plant. The second, NONFUEL EXPENSE, includes all nonfuel operations and maintenance expenses, such as those for coolants, repairs, maintenance supervision and engineering. This variable is less than ideal as a measure of materials, both because it reflects expenditures rather than quantities, and because it includes the wage bill for the employees counted in EMPLOYEES, although that expense is not separately delineated in our data. As NONFUEL EXPENSES includes payroll costs, both this and EMPLOYEES will reflect changes in staffing. ${ }^{34}$ The third input is the quantity of fuel consumed by type of fuel (tons of coal, barrels of oil, and mcf of natural gas). We convert fuel into BTUs using the reported annual plant-specific Btu content of each fuel to obtain total BTU input at the plant for each year.

Input prices pose a challenge. We do not observe firm- or plant-level wages. Our basic specifications use the variable WAGE, reflecting the Bureau of Labor Statistics state-level average utility wage by ownership type: investor-owned or publicly-owned. For MUNI plants in states without a publicly-owned utility wage series, we impute wage to be the product of investor-owned utility wages for that state and the average ratio of publicly- to investor-owned utility wages overall. This variable is problematic: not only does it measure firm-specific wages with error, but it is susceptible to the potential endogeneity of wages to the regulatory environment. ${ }^{35}$ We have experimented with

restructured wholesale markets may face even stronger incentives to be available when demand peaks because this is when prices are highest.

${ }^{34}$ The elasticity of NONFUEL EXPENSES with respect to EMPLOYEES is about .5 in our data, broadly consistent with our back of the envelope calculations suggesting that labor costs are roughly half of the total nonfuel operating budget.

${ }^{35}$ Hendricks (1975) suggests that utilities may bargain less aggressively over input prices such as wages during periods in which higher costs can be readily passed on to customers through higher regulated prices, and more aggressively when the firm is likely to be the residual claimant to cost savings. In other industries, regulatory reform has sometimes been associated with substantial reductions in wages, suggesting rentsharing under regulation (see Nancy L. Rose, 1987, on the trucking industry). Moreover, electricity workers tend to be highly unionized, and unions may bargain over employment terms as well as wages. These 
specifications that instrument for utility wages with the state average wages of workers in comparable labor markets, including natural gas distribution, petroleum refining and hazardous waste treatment facilities. While this instrument may in theory better reflect an exogenous opportunity wage for workers at power plants, the results using this are much noisier (though the non-WAGE coefficients are not materially affected). We therefore use WAGE in our basic specifications. We do not have reasonable indices for the materials prices that comprise NONFUEL EXPENSES, even at the state-industry level. Our empirical model of NONFUEL EXPENSES therefore corresponds to an input demand equation with constant real relative prices and a price coefficient of one.

The final input is the capital stock of the plant, which we measure by plant capacity and vintage. Our data record the plant capacity in megawatts. We combine this with information on unit retirements to define plant-epochs. Each plant is assigned a unique identifier. Any time the capacity of the plant is significantly changed, we create a new identifier and associated new plant-epoch specific effect. This allows capital changes to alter the underlying input efficiency of the plant. There may be variation within plantepoch when "scrubbers" (flue-gas desulfurization systems, or FGDs), are installed to reduce sulfur-dioxide emissions by some coal plants. SCRUBBERs affect the environmental output, unmeasured by $\ln (N E T M W H)$, which may suggest less efficient operation conditional only on observed output. We therefore include a direct control for the presence of a SCRUBBER.

Operational plant data are supplemented with information on state-level restructuring activity. For each state, we have identified (i) the date at which formal hearings on restructuring began, (ii) the enactment date for legislation restructuring the 
state's utility sector, if any, (iii) the implementation date for retail access under that legislation, and (iv) associated aspects of restructuring such as rate freezes and mandatory divestiture of generation. Testing for restructuring-specific shocks requires a determination of how to match this information with firm decisions: when were plant operators in a given state likely to have begun responding to a policy change?

Consultations with industry participants and readings of these events suggest that utilities often acted in advance of final legislative or regulatory outcomes. The process leading to state restructuring typically lasted a number of years, allowing utilities to anticipate the coming change, and alter their behavior in advance. For example, Boston Edison's 10-K filed in March 1994 discussed Massachusetts' consideration of restructuring, stating "The Company is responding to the current and anticipated competitive pressure with a commitment to cost control and increased operating efficiency without sacrificing quality of service or profitability" (Boston Edison, 1994, p. 6). ${ }^{36}$ Massachusetts had just begun holding formal hearings on restructuring the industry in 1994. Utilities may have phased input changes, especially those involving labor and particularly unionized workers. Moreover, as policy changes were discussed, rates were frozen in many states, either explicitly by policy makers or in effect by implicit PUC decisions not to hear new rate cases, enabling utilities to capture the savings from incremental cost reductions. ${ }^{37}$

opportunity cost to managers of the marginal unit of labor.

${ }^{36}$ A similar theme was echoed by many other utility executives. For example, in a 1993 news story on PECO's early retirement plan, Chairman and CEO Joseph Paquette described "trying to improve the company's competitive position by emphasizing a more productive work force. Employees are receiving extensive training for quality, and the company is looking at modifying its salary structures to promote pay for performance. Paquette said such programs are needed to help the company conduct business in an evolving, less-regulated power generation environment. 'We have to be prepared for this more competitive world,' he said" ("Philadelphia Electric: Cites Effect of Cost-Cutting Plan," Dow Jones News Service, May 27, 1993).

${ }^{37}$ As noted earlier, some of these changes may have also affected utilities in non-restructuring states. For example, the number of utility rate cases dropped dramatically in the 1990s, implying that many utilities may have been short- or medium-run residual claimants to cost reductions. Knittel (2002) identifies a number of incentive regulations adopted in various jurisdictions during the 1990s. Many of the fuel-related 
In this work, we allow restructuring effects to begin with the opening of formal hearings on restructuring. The primary variable of interest, RESTRUCTURED, is an indicator variable that turns on for investor-owned plants with the start of formal proceedings in a state that eventually passed restructuring legislation. ${ }^{38}$ If utilities did not respond until restructuring legislation or regulation was enacted and the policy uncertainty resolved, RESTRUCTURED will underestimate the true effect by averaging in nonresponse years. To evaluate this possibility we introduce a second variable, $L A W$ PASSED, an indicator equal to one beginning in the year the state passes restructuring legislation. ${ }^{39}$ A third variable, RETAIL ACCESS, indicates the start of retail access for plants in the states that implemented retail competition within our sample. ${ }^{40}$ If actual implementation of retail access and the associated wholesale market reforms is important to efficiency gains, it will be reflected in an incremental effect of RETAIL ACCESS.

To compare differences in the path of municipally-owned plants over the restructuring time period, we define the indicator variables MUNI*POST 1987 and MUNI*POST 1992. The first is equal to one for all non-investor-owned plants after 1987,

regulations (modified pass-through clauses, heat rate and equivalent availability factor incentive programs) were strongly correlated with ultimate restructuring. Some of the broader regulations (e.g., price caps and revenue decoupling programs) were almost orthogonal to eventual restructuring.

${ }^{38}$ The RESTRUCTURED variable is based on whether a state had passed legislation as of mid-2001. To date, there has been no additional restructuring and some states have delayed or suspended planned restructuring activity in the aftermath of the California electricity crisis. Plants are assigned to the state in which they are regulated. A plant located in one state may be owned by a company with exclusive service territory in a different state. In this case, the ownership state is the one for which the regulatory policy is measured. Some plants are owned by a company with service territory in more than one state and some plants are owned by several companies that are regulated by different states. In the regression analysis, we found that separately characterizing "mixed" regulation and "shared" plants had very little impact on our results.

${ }^{39}$ There is on average about a 2.6-year lag between the initiation of hearings and the passage of the law. We have experimented with a number of alternative measures of restructuring activity, including variables that begin with hearings regardless of restructuring outcomes, those that measure years since hearings were initiated for states that eventually restructured, and the presence of restructuring-associated rate freezes. None of these materially changes the conclusions we draw below.

${ }^{40}$ While RESTRUCTURED indicates approval of retail access competition, the specified phase-in of retail access was often slow. Only seven states implemented retail access during our sample period, four in 1998 and three in 1999. 
the second for all non- IOU plants after 1992. MUNI*POST 1987 allows for the possibility that relative input demand growth for IOU and publicly-owned plants diverged in the late 1980s and early 1990s, when many states began to experiment with incentive regulation and during which time the earliest discussion of increased competition took place. MUNI*POST 1992 captures the incremental change in relative input demand growth across IOUs and publicly-owned plants during the restructuring period. Because the designation of the pre-reform period is inherently imperfect, we also report the unrestricted annual time path of input demand growth (see Figures 1 and 2).

Details on the data sources and summary statistics are provided in the data appendix. Table 1 reports summary statistics for plant-level data in 1985 across three categories: investor-owned plants in states that eventually restructured, investor-owned plants in states that did not restructure, and non-IOU (MUNI) plants. We use 1985 to ensure that comparisons are made prior to any significant changes across states in the competitive or regulatory environment, even well before restructuring initiatives.

This table suggests that the plants in these groups are not random draws from the same population. The first three variables measure employees and nonfuel operating expenses, scaled by the plant's capacity, and fuel use in millions of British thermal units (mmBtus), scaled by the plant's output. In 1985, before state-level restructuring initiatives were considered, IOU plants in states that eventually restructured used more employees and nonfuel operating expenses per MW of capacity than did IOU plants in non-restructuring states (see the difference in means test in column 4). Employment by municipally-owned plants is not statistically distinguishable from employment at restructuring IOU plants, but MUNI plants appear to have lower levels of nonfuel expenses. Differences in heat rates and capacity factors are not significant for any cross- 
sample comparison. The last four rows suggest notable differences in the stock of plants across these three groups. Although IOU plants are very similar in size across regimes, MUNI plants tend to be substantially smaller. IOU plants in restructuring states tend to be older, more likely to use gas, and less likely to use coal, than their counterparts in nonrestructuring states. IOU plants in restructuring states also tend to be older and less likely to use coal than their MUNI counterparts. The regression analysis will control for these differences directly or with the use of plant-epoch effects.

If investor-owned utilities achieved efficiency improvements when facing impending restructuring of the generation sector, one would expect to see a relative decrease in the cost of generation for affected companies, and little difference in the change in transmission and distribution costs between the affected and not affected states since restructuring programs leave transmission and distribution comparatively untouched. If restructuring did not affect operating efficiency in the generation sector, we might expect similar changes in generation expenses across restructuring and non-restructuring companies, and perhaps similar patterns of cost changes across the transmission, distribution, and generation sectors.

Table 2 displays the mean changes in cost per MWh for investor-owned utilities in restructuring and non-restructuring states between 1990 and $1996{ }^{41}$ Unlike distribution and transmission costs, generation costs per MWh decrease considerably over this period, and by considerably more at companies in restructuring states, significant at the 6 percent level. Moreover, the difference in cost changes across regimes is not significant for either the transmission or distribution costs. These aggregate statistics may suggest that the

\footnotetext{
${ }^{41}$ For this analysis, we rely on data reported annually by utility companies to the FERC in the Form 1, page 320,321 , and 322 respectively. We use a balanced sample composed of all companies with data reported for all three sectors in both 1990 and 1996. This amounts to 48 companies in states that did not restructure and 72 in states that did restructure.
} 
division of the utility company faced with competition (the generating sector) responded with a decrease in costs, while other sectors and companies not faced with competition did not share this response.

\section{Estimating the Effects of Restructuring on Input Use}

Following equation (11), we estimate the influence of restructuring on the use of input $N$ (EMPLOYEES, NONFUEL EXPENSE, and BTUs) with the following basic regression model:

$$
\begin{aligned}
& \ln \left(\mathrm{N}_{\mathrm{irt}}\right)= \beta_{1}{ }^{\mathrm{N}} \ln \left(\text { NET MWH }_{\mathrm{irt}}\right)+\beta_{2}{ }^{\mathrm{N}} \ln \left(\text { PRICE }^{\mathrm{N}} \text { irt }\right)+\beta_{3}{ }^{\mathrm{N}} \text { SCRUBBER } \\
& \text { irt }
\end{aligned}
$$

where we allow for nonunity coefficients on the output term $\left(\beta_{1}{ }^{\mathrm{N}}\right)$ for all equations and on the input price term $\left(\beta_{2}{ }^{\mathrm{N}}\right.$ on WAGE) in the EMPLOYEES equation, ${ }^{42}$ and measure the impact of having a scrubber on plant input use with the variable SCRUBBER. $\alpha_{\mathrm{i}}^{\mathrm{N}}$ is a time-invariant fixed effect for input $N$ at plant-epoch $i$, which may contain a state-specific and ownership-specific error that will not be separately identified. These plant-specific effects control for much of the expected variation in input use across plants arising from heterogeneous technologies, state or regional fixed factors, and basic efficiency differences. They also control for differences in the plant mix between restructuring and non-restructuring states by comparing each plant to itself over time, removing any timeinvariant plant effects. As a Hausman test (Jerry Hausman, 1978) rejects the exogeneity of the plant-epoch effects, all reported results include plant-epoch fixed-effects. $\delta_{t}{ }^{N}$ is an

\footnotetext{
${ }^{42}$ Recall that we do not have a price associated with nonfuel expenses, and that according to equation (10), fuel prices should not enter into the fuel input function. We experimented with using a variable measuring the price of a given plant's fuel relative to the prices of other fuels in the same region as an instrument for output but the variable had no power in the first stage.
} 
industry-level effect in year $\mathrm{t}$, which controls for systematic changes in input demand common to all plants in that year.

The error term, $e_{\text {irt }}$, combines the deviation of actual from probable output, $\beta_{1}{ }^{\mathrm{N}} \varepsilon_{\text {irt }}$, and the input $N$-specific productivity shock to plant $i$ in regime $r$ at time $t, \varepsilon_{\text {irt }}{ }^{\mathrm{N}}$. This error is unlikely to be independent over time for a given plant; the data suggest considerable persistence in input shocks, particularly for labor, from year to year. The estimated rho assuming a first-order serial correlation process ranges from roughly 0.33 for nonfuel expenses to 0.75 for labor. As discussed earlier, the estimation must also account for endogeneity of output, measured in these specifications as the net generation by the plant in megawatt-hours (NET MWH). We therefore implement a GLS-IV estimation strategy, using a Prais-Winsten GLS correction for first-order serial correlation at the plant level, ${ }^{43}$ and instrumenting for plant output with a nonlinear function of state demand (the log of total state electricity sales, which is a consumption rather than production measure). ${ }^{44}$

We consider specifications that include interactions of IOU ownership with the three primary restructuring indicator variables described in section III: RESTRUCTURED, LAW PASSED, and RETAIL ACCESS. In the input regressions, a negative coefficient on the restructuring variables would imply increased input efficiency associated with the regulatory reform. The core results for the input analysis are presented in table 3 for EMPLOYEES, table 4 for NONFUEL EXPENSES and table 5 for BTU. We first discuss the results for employment and nonfuel expenses, and then discuss the results for fuel use.

\footnotetext{
${ }^{43}$ Reported standard errors also correct for possible correlation across observations at the state-year level.

${ }^{44}$ State demand is an important determinant of plant-level output, but should be unaffected by plant productivity shocks. The F-statistic on the instrument from the first stage estimates for the NONFUEL EXPENSE and BTU specifications (i.e. excluding the WAGE variable) is 11.9. We have explored the sensitivity of our results to alternative instrument choices; these are reported in the FRW (2007) Technical Appendix.
} 
Column 1 of tables 3 and 4 reports results from generalized least squares (GLS) estimation of our basic specification, treating plant output as exogenous. The primary coefficient of interest, IOU*RESTRUCTURED, captures the mean differential in input use for investor-owned plants in states that eventually pass restructuring legislation. This is, measured over the period following the first restructuring hearings, relative to the untreated IOU plants in non-restructuring states. The results suggest statistically and economically significant declines in input use associated with regulatory restructuring. Employment declines by roughly 3 percent (1 percent standard error) and nonfuel expenses decline by roughly 9 percent ( 2 percent standard error), ${ }^{45}$ relative to IOU plants in regimes that have not restructured. ${ }^{46}$

The second notable result is the dependence of the implied restructuring effect on the control group. While IOU plants in restructuring states exhibit modest reductions in employment and nonfuel expenses relative to IOUs in non-restructuring states, the implied reductions are substantially larger when compared to public and cooperative plants. The positive MUNI*POST 1987 coefficients suggest that all IOU plants improved their efficiency relative to MUNI plants during the late 1980s and early 1990s. This gap widened further after 1992 (see MUNI*POST 1992). This suggests that even IOU plants in non-restructuring regimes improved their relative input use to a significant extent, perhaps in response to latent threats of increased competition and restructuring. Employment use was 6 percent lower for IOU plants in restructuring states relative to

\footnotetext{
${ }^{45}$ We use $\left[\exp \left(\varphi_{\mathrm{r}}{ }^{\mathrm{N}}\right)-1\right]^{*} 100$ to approximate the implied percentage effect of IOU* RESTRUCTURED on input use.

${ }^{46}$ Note that the Cobb-Douglas functional form assumption for labor and nonfuel expenses suggests that the coefficient on output should be one, substantially larger than the coefficients estimated in these regressions. We have estimated production functions in EMPLOYEES and NONFUEL EXPENSES using more flexible functional forms than Cobb-Douglas, and the results also suggest efficiency gains associated with restructuring. We have also estimated instrumental variables versions of equations (7) and (8) that include the other input instead of output and obtained very similar results to those reported here.
} 
MUNI plants after 1992, and nonfuel expenses declined by 11 percent relative to the MUNI benchmark (computed as the IOU*RESTRUCTURED minus MUNI*POST 1992 coefficients in tables 3 and 4). We return to this issue in greater detail below.

The remaining columns in each table report instrumental variables (GLS-IV) estimates of the input equations that treat potential measurement error and simultaneity bias with respect to output, as well as serial correlation of shocks. For EMPLOYEES, estimates of the output coefficient almost double relative to the GLS estimates, although the imprecision of the GLS-IV estimates make it impossible to reject equivalence, and in absolute magnitude, both estimates of the labor demand elasticity with respect to output are quite small, at 4 percent ( 0.5 percent standard error) for GLS and 7 percent ( 7 percent standard error) for GLS-IV. Consistent with this, the estimated effect of restructuring on labor demand is essentially unaffected by the treatment of output exogeneity. For NONFUEL EXPENSES, however, instrumenting for output increases its estimated elasticity more than fourfold, to over 50 percent ( 9 percent standard error). This is consistent with a negative correlation of input shocks and output, as for example, if large maintenance expenditures are associated with outages at the plant. With the strong link between output and nonfuel expenses implied by these results, correcting for output endogeneity also has a substantial effect on the estimated effect of restructuring. The estimated coefficient on the IOU*RESTRUCTURED coefficient drops by almost half, to -5 percent (2.6 percent standard error), bringing it into the range of the estimated labor input effect.

Columns 3 and 4 of the tables explore robustness to alternative measures of restructuring, maintaining the use of GLS-IV estimates. Measuring restructuring by $L A W$ PASSED in column 3 yields smaller (and statistically indistinguishable from zero) 
coefficients in both the employment and the nonfuel expense regressions, perhaps because the baseline period now includes efficiency improvements made between the initiation and passage of legislation. Column 4 adds the RETAIL ACCESS variable. We note that its coefficient is identified by no more than two years of data in the seven states that implement retail access as of 1999 , and it is not particularly stable across alternative instrument sets or to changes in the sample. In these basic specifications, the coefficient on RETAIL ACCESS in labor demand is quite imprecisely estimated, though the point estimate suggests an additional -3 percent ( 5 percent standard error) change in employment when states implement retail access. The estimated impact of retail access on nonfuel expenses is substantially larger, at -17 percent (6.5 percent), though its sensitivity to balancing the sample precludes confidence in the estimate (see footnote 25).

Finally, in column 5 of each table, we report results that use an alternative measure of competitive pressure. Policy changes in the late 1980s and early 1990s set the stage for increased nonutility generation, but the impact of that change varied substantially across states. We construct an indicator, HIGH NONUTILITY GENERATION, which turns on in 1993 if the plant is in a state that has above median penetration of nonutility generation as of 1993. This measure should capture any utility responses to higher intensity of actual generation competition from unregulated market participants. ${ }^{47}$ The estimated impact of high levels of nonutility generation on employment at IOU plants is slightly smaller and noisier than RESTRUCTURED estimates (at -2.2 percent, standard error, 1.9 percent). For nonfuel expenses, high penetration by non utility generation appears to have no detectable direct effect on IOU plant input use (-1 percent, standard error, 3 percent).

\footnotetext{
${ }^{47} \mathrm{We}$ include this in column 5 as a replacement for restructuring policy variables, but have also estimated models that include direct effects of RESTRUCTURED and HIGH NONUTILITY GENERATION as well as their interaction.
} 
In the instrumental variables results, as in the GLS results, the implied magnitude of the restructuring effect depends upon the chosen benchmark or control group. The gap in IOU input demand between restructuring and non-restructuring states, conditional on output, is generally statistically and economically significant, though relatively modest. The performance gain of an IOU plant in a restructured regime relative to MUNI plants over the same period is larger, on the order of 6 percent reductions in employment and 12 percent reductions in nonfuel expenses. ${ }^{48}$

To provide further insight into the question of benchmark group, we re-estimate the basic model of column (4) without the IOU*RESTRUCTURED and MUNI*POST 1992 variables, but allowing for separate year effects for each of three categories of plants: IOU plants in states that eventually restructure, IOU plants in states that do not restructure, and MUNI plants. Figures 1 (employees) and 2 (nonfuel expenses) plot the estimated year effects for each plant group. The figures suggest greater divergence between MUNI and IOU plants in both input measures as the 1990s progress. As this is a period of increasing competitive pressures and substantial movement toward restructuring, these patterns suggest to us that there is considerable information in the MUNI benchmark comparisons.

Table 5 reports results from variants of our basic specification for fuel inputs. In column 1, GLS results suggest an output elasticity well below unity $(0.912$, standard error 0.004), and an implied reduction in fuel use associated with IOU plants in restructuring regimes (-1.4 percent, standard error 0.4 percent). Columns 2 through 5 report results for specifications that instrument for output. The estimated output elasticity is quite close to, and statistically indistinguishable from, unity. The estimated effects of restructuring or

\footnotetext{
${ }^{48}$ The results are robust to a variety of more flexible specifications of the MUNI controls over time and to
} 
NON UTILITY GENERATION competition are all small and statistically indistinguishable from zero (negative in columns 2 and 4, positive in columns 3 and 5). There is no measurable effect of restructuring on fuel efficiency relative to IOU plants in nonrestructuring states. Nor is there evidence of significant differences between IOU plants and MUNI plants. The MUNI *POST 1992 coefficient point estimates appear virtually identical to the IOU restructuring coefficients, and are similarly indistinguishable from zero. $^{49}$

While the data do not suggest gains in fuel efficiency from restructuring within our sample, a caveat is in order. Although variations on the order of even $0.5-1.0$ percent in fuel productivity are economically significant, it may be difficult to measure these sufficiently precisely with our aggregated data. Fuel efficiency at a plant is heavily influenced by factors such as the allocation of output across units at a plant, the number of times its units are stopped and started, and for how long the units were running below their capacity. Our inability to measure or control for possible changes in these operational characteristics may make it particularly difficult to capture any changes in fuel efficiency. Improving our understanding of fuel efficiency effects seems an important direction for future research.

\section{Testing robustness of the RESTRUCTURED effect}

We have analyzed the robustness of these results to a variety of alternative specifications of the input demand equations. We report selected results below; additional robustness tests are available in our Technical Appendix. Given the null results

allowing differential MUNI output elasticity coefficients.

${ }^{49}$ We obtained similar null results when we estimated specifications using the log of plant heat rate (BTUs/MWhs) as the dependent variable, controlling for output. 
in our basic fuel use regressions, we focus on labor and nonfuel expense input choices in this analysis.

Our first tests divide the sample along size and age lines; recall that these are the dimensions on which MUNI plants appear to differ from IOU plants. In tables 6 (employees) and 7 (nonfuel expenses), we report results for "larger" versus "smaller" plants (columns 1 and 2), and "old" versus "new" plants (columns 3 and 4). These are relative cuts that divide the sample at roughly the median of size (575 MW) and the median of age (oldest unit is built after 1960). For all specifications, IOU plants in restructured regimes exhibit lower input use than do IOU plants in nonrestructured regimes (see the coefficients on IOU*RESTRUCTURED), though the magnitude of the estimated effect varies with the subsample. Estimated IOU restructuring effects suggest very similar employment reductions at $L A R G E R$ and SMALLER plants and slightly greater employment reductions at $N E W$ plants than at $O L D$ plants, though the point estimates are not significantly different across the subsamples. Nonfuel expense reductions appear to be greatest for LARGER and NEW plants - about twice the estimated magnitude for those at SMALLER and OLD plants. More interesting, perhaps, is the comparison to MUNI plants. They appear indistinguishable from IOUs in input use at OLD plants (see column 3 of both tables) and in employment at LARGER plants. For newer and SMALLER plants (where the MUNI density is greatest), the post-1992 performance gap is at least as large as in the previous tables. It is difficult to tell whether the patterns in these subsamples reflect real differences or a greater ability of the data to pin down performance effects for the denser part of the sample. Moreover, it does not appear that the overall conclusions of the earlier tables with respect to the MUNI benchmark are substantially affected by these sample differences. 
In table 8 , we consider whether the results are explained by a regression to the mean phenomenon among IOU plants: is the gain in efficiency among plants in restructuring regimes because they had on average low productivity draws prior to restructuring, and simply return to mean efficiency over time? To examine this, we identify high- and low-input use plants and investigate the extent to which efficiency gains at the higher input use plants are offset by efficiency losses at low input use plants. To separate plants into "low input" and "high input" categories, we predict input use from a regression on data for the pre-restructuring period, 1981 - 1992. We calculate the mean residual for each plant and classify plants with mean residuals above zero as " $H I G H$ INPUT" and those below zero as "LOW INPUT." We then interact these indicators with the restructuring variables, which are post-1992, and re-run the basic regression specification allowing input responsiveness to restructuring to differ across plant type. ${ }^{50}$ The results in table 8 suggest that most of the restructuring-related input declines relative to IOU plants in nonrestructured regimes are associated with high input-use IOU plants, with reductions in the neighborhood of 10 percent to 12 percent (standard errors, about 3 percent) for both labor and nonfuel expenses for these plants. The coefficients on the IOU*RESTRUCTURED*LOW INPUT interactions are economically and statistically indistinguishable from zero, contrary to mean reversion predictions. This may suggest that the form of efficiency improvement was to bring less efficient plants into line with more efficient plants. This is consistent with discussions we have had with several utility managers, who claimed that restructuring led their firms to identify high-cost plants as those disadvantaged in the dispatch order, and to focus attention on bringing the costs of those plants closer to an efficient benchmark plant. Interestingly, the MUNI benchmark

\footnotetext{
${ }^{50}$ The direct effects of LOW INPUT and HIGH INPUT categories are absorbed in the plant fixed effects.
} 
suggests that LOW INPUT MUNI plants became more expensive, with little relative change at the HIGH INPUT MUNI plants after 1992.

We have implemented a number of additional robustness checks, including alternative instruments and instrument strategies and more flexible dynamics in input choice. A more complete discussion and example results are available in our Technical Appendix. Of particular note were specifications that allow for the possibility of fixed costs of input adjustments. We find that the restructuring estimates are robust to allowing inputs to respond to future as well as current output levels. Lagged values of output (following Blundell and Bond, 1998, 2000) proved to be weak instruments in our GLS-IV model.

\section{Conclusion}

This research provides some of the first estimates of the impact of electricity generation sector restructuring in the United States on plant-level efficiency. The results suggest restructuring may yield substantive medium-run efficiency gains. The estimates suggests that IOU plants in restructuring regimes reduced their labor and nonfuel operating expenses by three to five percent in anticipation of increased competition in electricity generation, relative to IOU plants in states that did not restructure their markets. The estimated efficiency gains are even larger when compared to a benchmark based on municipal, federal, and cooperative plants: on the order of six percent reductions in labor use and twelve percent reductions in nonfuel operating expenses relative to non-IOU plants over the same time period. There is little evidence of increases in fuel efficiency relative to plants in non-restructuring regimes, although the power of these tests is limited given the plausible range of possible fuel use improvements. 
These same-plant reductions in input use suggest an important role for marketbased incentives and competition in promoting technical efficiency, buttressing the findings of Nickell (1996), Ng and Seabright (2001), and Galdón-Sánchez and Schmitz (2002), among others. This finding is particularly interesting given the industry context. Generating plant technology is reasonably well understood by engineers, and the prerestructuring industry was remarkably open in sharing detailed information on plant operations and input use across plants and firms. ${ }^{51}$ Presumably, external benchmarks also were more accessible in this setting than in most industries. This could suggest that competition induced greater effort on cost reduction by increasing the sensitivity of returns to managerial and worker effort, rather than by reducing informational asymmetries over managerial effort (Nickell, 1996).

Additional work remains to be done to fill out the picture of the overall effects of restructuring on electricity industry efficiency. ${ }^{52}$ We began by looking at operating efficiency within existing utility plants both because this is one of the few places where gains are likely to show up before restructured wholesale markets open up and because rich data are available on utility-owned plants. As our results suggest, even these data are inadequate for the fine-level analysis required to estimate within and across-plant changes in fuel efficiency. This analysis will require datasets with both cleaner measures of fuel efficiency and richer information on independent factors that affect fuel use. Finally, assessing whether investment decisions are made more efficiently after restructuring requires more time, and access to better nonutility data. Since power plants are so long-

\footnotetext{
${ }^{51}$ Our access to detailed, publicly-available, plant-identifiable data corroborates this.

${ }^{52}$ See Wolfram (2005) for a discussion of the general issues involved in assessing different types of efficiency changes accompany electricity restructuring.
} 
lived, very few new additions are made each year, and currently we have no more than a handful of anecdotes about investment after restructuring.

It is important to recognize that these efficiency estimates are, however, only one input to judging the ultimate benefit of restructuring policies. The overall assessment depends as well on the realized magnitude of potential dynamic efficiencies, and offsetting effects from higher investment expenditures, restructuring costs, the loss of coordination and network economies within vertically integrated systems, and the exercise of market power in unregulated generation markets. Dynamic costs could be higher if restructuring reduces knowledge sharing that affects productivity growth over time. It is possible, however, that longer run benefits will be greater if firms respond to the new incentives created by restructuring with investments in both human and physical capital that further enhance efficiency. If California's crisis does not induce reversals of the restructuring movement, and regulators do not shut down data reporting and researcher access to detailed plant-level data, time may enable us to distinguish among these possibilities. 


\section{References}

Ackerberg, Daniel A., Kevin Caves, and Garth Frazer. 2005. "Structural Identification of Production Functions." UCLA mimeo.

Ai, Chunrong, and David E. M. Sappington. 2002. “The Impact of State Incentive Regulation on the U.S. Telecommunications Industry.” Journal of Regulatory Economics, 22(2): 133-160.

Baggs, Jen, and Jean-Etienne de Bettignies. Forthcoming. "Product Market Competition and Agency Costs." Journal of Industrial Economics.

Bailey, Elizabeth E. 1986. "Price and Productivity Change Following Deregulation: The US Experience.” Economic Journal, 96(381): 1-17.

Blundell, Richard, and Stephen Bond. 1998. "Initial Conditions and Moment Restrictions in Dynamic Panel Data Models.” Journal of Econometrics, 87(1): 115-143.

Blundell, Richard, and Stephen Bond. 2000. “GMM Estimation with Persistent Panel Data: An Application to Production Functions.” Econometric Reviews, 19(3): 321340 .

Borenstein, Severin, James B. Bushnell, and Frank A. Wolak. 2002. "Measuring Market Inefficiencies in California's Restructured Wholesale Electricity Market.” American Economic Review, 92(5): 1376-1405.

Boston Edison Co. 1994. Annual Report and 10-K. http://www.sec.gov/Archives/edgar/data/13372/0000950135-94-000231.txt

Bushnell, James B., and Catherine D. Wolfram. 2005. "Ownership Change, Incentives and Plant Efficiency: The Divestiture of U.S. Electric Generation Plants." Center for the Study of Energy Markets Paper CSEMWP-140. 
Christensen, Laurits R., and William H. Greene. 1976. "Economies of Scale in U.S. Electric Power Generation." Journal of Political Economy, 84(4): 655-676.

Fabrizio, Kira, Nancy L. Rose, and Catherine D. Wolfram. 2007. “Does Competition Reduce Costs? Assessing the Impact of Regulatory Restructuring on U.S. Electric Generation Efficiency.” National Bureau of Economic Research Working Paper 11001. Revised.

Galdón-Sánchez, José E., and James A. Schmitz, Jr. 2002. “Competitive Pressure and Labor Productivity: World Iron Ore Markets in the 1980s." American Economic Review, 92(4): 1222-35.

Griliches, Zvi, and Jacques Mairesse. 1998. "Production Functions: The Search for Identification.” In Econometrics and Economic Theory in the 20th Century, ed. Steinar Strøm, 169-203. Cambridge, UK: Cambridge University Press.

Hausman, Jerry A. 1978. "Specification Tests in Econometrics." Econometrica, 46(6): $1251-1271$

Hendricks, Wallace E. 1975. "The Effect of Regulation on Collective Bargaining in Electric Utilities.” Bell Journal of Economics and Management Science, 6(2): 451465.

Hiebert, L. Dean. 2002. "The Determinants of the Cost Efficiency of Electric Generating Plants: A Stochastic Frontier Production Approach.” Southern Economic Journal, 68(4): 935-946.

Joskow, Paul L. 1974. "Inflation and Environmental Concern: Structural Change in the Process of Public Utility Price Regulation.” Journal of Law and Economics, 17(2): 291-327. 
Joskow, Paul L. 1997. "Restructuring, Competition and Regulatory Reform in the U.S. Electricity Sector.” Journal of Economic Perspectives, 11(3): 119-138.

Joskow, Paul L., and Edward Kahn. 2002. “A Quantitative Analysis of Pricing Behavior in California's Wholesale Electricity Market during Summer 2000.” Energy Journal, 23(4): 1-35.

Joskow, Paul L., and Richard Schmalensee. 1987. "The Performance of Coal-Burning Electric Generating Units in the United States: 1960-1980.” Journal of Applied Economics, 2(2): 85-109.

Knittel, Christopher R. 2002. “Alternative Regulatory Methods and Firm Efficiency: Stochastic Frontier Evidence from the US Electricity Industry.” Review of Economics and Statistics, 84(3): 530-540.

Kleit, Andrew, and Dek Terrell. 2001. "Measuring Potential Efficiency Gains From Deregulation of Electricity Generation: A Bayesian Approach.” Review of Economics and Statistics, 83(3): 523-530.

Kridel, Donald J., David E. M. Sappington, and Dennis L. Weisman. 1996. "The Effects of Incentive Regulation in the Telecommunications Industry: A Survey.” Journal of Regulatory Economics, 9(3): 269-306.

Laffont, Jean-Jacques, and Jean Tirole. 1993. A Theory of Incentives in Procurement and Regulation. Cambridge, MA: MIT Press.

Levinsohn, James, and Amil Petrin. 2003. "Estimating Production Functions Using Inputs to Control for Unobservables.” Review of Economic Studies, 70(2): 317-41.

Nerlove, Marc. 1963. "Returns to Scale in Electricity Supply." In Measurement in Economics, 167-198. Stanford, CA: Stanford University Press. 
Ng, Charles K., and Paul Seabright. 2001. "Competition, Privatization, and Productive Efficiency: Evidence from the Airline Industry." Economic Journal, 111(473): 591-619.

Nickell, Stephen J. 1996. “Competition and Corporate Performance.” Journal of Political Economy, 104(4): 724-746.

Olley, G. Steven, and Ariel Pakes. 1996. "The Dynamics of Productivity in the Telecommunications Equipment Industry.” Econometrica, 64(6): 1263-1297.

Park, B. U., R. C. Sickles, and L. Simar. 1998. "Stochastic Panel Frontiers: A Semiparametric Approach.” Journal of Econometrics, 84(2): 273-301.

Primeaux, Walter J. 1977. “An Assessment of X-Efficiency Gained through Competition." Review of Economics and Statistics, 59(1): 105-08.

Rose, Nancy L. 1987. "Labor Rent Sharing and Regulation: Evidence from the Trucking Industry." Journal of Political Economy, 95 (6): 1146 - 1178.

Schumpeter, Joseph A. 1942. Capitalism, Socialism and Democracy. New York, NY: Harper \& Brothers.

Syverson, Chad. 2004. "Market Structure and Productivity: A Concrete Example." Journal of Political Economy, 112(6): 1181-1222.

U.S. Energy Information Administration. 2003. "Status of State Restructuring Activity Timeline as of February 2003.” http://www.eia.doe.gov/cneaf/chg_str/ retail_access_timeline.html [accessed November 23, 2003].

Van Biesebroeck, Johannes. 2003. "Productivity Dynamics with Technology Choice: An Application to Automobile Assembly." Review of Economic Studies, 70(1): 167198. 
Vives, Xavier. 2006. “Innovation and Competitive Pressure.” IESE Business School University of Navarra Working Paper No. 634.

White, Matthew W. 1996. "Power Struggles: Explaining Deregulatory Reforms in Electricity Markets.” In Brookings Papers on Economic Activity: Microeconomics 1996, 201-250. Washington, DC: The Brookings Institution.

Wolak, Frank A. 2006. "Regulating Competition in Wholesale Electricity Supply." National Bureau of Economic Research Conference on Regulatory Reform: Lessons Learned. Mimeo.

Wolfram, Catherine D. 2005. "The Efficiency of Electricity Generation in the U.S. after Restructuring.” In Electricity Deregulation: Choices and Challenges, ed. James Griffin and Steve Puller, 227-255, Chicago, IL: University of Chicago Press. 
Table 1: Summary of Plant Characteristics in 1985, By Ownership and Restructuring Regime as of 2001

\begin{tabular}{|c|c|c|c|c|c|}
\hline \multirow[b]{2}{*}{ Variable } & \multirow{2}{*}{$\begin{array}{c}\text { RESTRUCTURED } \\
\text { IOU Plants } \\
(\mathrm{N}=249)\end{array}$} & \multirow{2}{*}{$\begin{array}{c}\text { NON- } \\
\text { RESTRUCTURED } \\
\text { IOU Plants } \\
(\mathrm{N}=192)\end{array}$} & \multirow{2}{*}{$\begin{array}{c}\text { MUNI } \\
\text { Plants } \\
(\mathrm{N}=105)\end{array}$} & \multicolumn{2}{|c|}{$\begin{array}{l}\text { Difference in Means } \\
\text { (t-statistic) }\end{array}$} \\
\hline & & & & $\begin{array}{c}\text { RESTRUCTURED - } \\
\text { NONRESTRUCTURED } \\
\text { IOUs }\end{array}$ & $\begin{array}{c}\text { RESTRUCTURED } \\
\text { IOUs - } \\
\text { MUNI }\end{array}$ \\
\hline EMPLOYEES / MW & $\begin{array}{c}0.29 \\
(0.22)\end{array}$ & $\begin{array}{c}0.26 \\
(0.14)\end{array}$ & $\begin{array}{c}0.27 \\
(0.13)\end{array}$ & $\begin{array}{r}0.04 * * \\
(2.07)\end{array}$ & $\begin{array}{c}0.02 \\
(1.12)\end{array}$ \\
\hline $\begin{array}{l}\text { NONFUEL EXPENSE/MW } \\
(\$ / M W)\end{array}$ & $\begin{array}{c}19909 \\
(14180)\end{array}$ & $\begin{array}{l}16742 \\
(9976)\end{array}$ & $\begin{array}{l}15369 \\
(9334)\end{array}$ & $\begin{array}{c}3167 * * \\
(2.75)\end{array}$ & $\begin{array}{c}4539 * * \\
(3.54)\end{array}$ \\
\hline HEAT RATE & 11 & 11 & 12 & -0.2 & -0.6 \\
\hline (Million Btu/MWh) & $(2.0)$ & (3.3) & $(5.9)$ & $(-0.90)$ & $(-0.97)$ \\
\hline CAPACITY FACTOR & 0.40 & 0.40 & 0.39 & -0.006 & 0.005 \\
\hline$(0.0-1.0)$ & $(0.21)$ & $(.20)$ & $(0.22)$ & $(-.30)$ & $(0.18)$ \\
\hline $\begin{array}{l}\text { MegaWatt Capacity } \\
(M W)\end{array}$ & $\begin{array}{l}805 \\
(658)\end{array}$ & $\begin{array}{c}801 \\
(645)\end{array}$ & $\begin{array}{c}679 \\
(601)\end{array}$ & $\begin{array}{c}3.6 \\
(0.06)\end{array}$ & $\begin{array}{l}126^{*} \\
(1.75)\end{array}$ \\
\hline $\begin{array}{l}\text { Age of Oldest Unit } \\
\text { (years) }\end{array}$ & $\begin{array}{l}28 \\
(11)\end{array}$ & $\begin{array}{l}24 \\
(13)\end{array}$ & $\begin{array}{l}19 \\
(11)\end{array}$ & $\begin{array}{l}3.5^{* *} \\
(2.96)\end{array}$ & $\begin{array}{l}8.4 * * \\
(6.40)\end{array}$ \\
\hline Percent COAL & 51 & 79 & 68 & $\begin{array}{l}-28 * * \\
(6.42)\end{array}$ & $\begin{array}{l}-16^{* *} \\
(2.91)\end{array}$ \\
\hline Percent GAS & 37 & 16 & 29 & $\begin{array}{l}20 * * \\
(5.03)\end{array}$ & $\begin{array}{c}8 \\
(1.48)\end{array}$ \\
\hline
\end{tabular}

In the first three columns, standard deviations are in parentheses.

$*$ denotes differences significant at 0.10 level $* *$ denotes differences significant at 0.05 level or better. 
Table 2: Percentage Change in Costs per MWh from 1990 to 1996 Difference of Means Tests

Investor Owned Utilities in Non-restructuring versus Restructuring States

\begin{tabular}{lcccc}
\hline \hline & $\mathrm{N}$ & Distribution & Transmission & Generation \\
\hline Restructuring Mean & 72 & 1.5 & 13.1 & -13.5 \\
Non-restructuring & 48 & -1.6 & 12.6 & -5.1 \\
$\begin{array}{l}\text { Mean } \\
\text { Difference of means }\end{array}$ & & 3.1 & 0.4 & -8.3 \\
t-statistic & 0.70 & 0.06 & -1.87 \\
\hline & All measures are in nominal dollars.
\end{tabular}

All measures are in nominal dollars.

Transmission and distribution costs are per MWh sales to ultimate customers, while generation costs are per MWhs generated at company plants. 
Table 3: Labor Input Demand Estimates with Alternative Specifications of Restructuring Dependent variable: $\ln ($ EMPLOYEES)

\begin{tabular}{|c|c|c|c|c|c|}
\hline & (1) & (2) & (3) & (4) & (5) \\
\hline & GLS & GLS-IV & GLS-IV & GLS-IV & GLS-IV \\
\hline \multirow[t]{2}{*}{ Independent Variables } & Basic & Basic & Law Date & Retail & Non Utility \\
\hline & & & & Access & Generation \\
\hline \multirow[t]{2}{*}{ IOU*RESTRUCTURED } & $-0.032 * *$ & $-0.031 * *$ & & $-0.031 * *$ & \\
\hline & $(0.014)$ & $(0.015)$ & & $(0.014)$ & \\
\hline \multirow[t]{2}{*}{ IOU*LAW PASSED } & & & -0.013 & & \\
\hline & & & $(0.016)$ & & \\
\hline \multirow[t]{2}{*}{ IOU*RETAIL ACCESS } & & & & -0.031 & \\
\hline & & & & $(0.051)$ & \\
\hline \multicolumn{2}{|l|}{ IOU*HIGH NON } & & & & -0.022 \\
\hline \multicolumn{2}{|l|}{ UTILITY GENERATION } & & & & $(0.019)$ \\
\hline \multirow[t]{2}{*}{ MUNI*POST 1992} & $0.029 * *$ & $0.032 * * *$ & $0.036 * * *$ & $0.031 * * *$ & $0.029 * *$ \\
\hline & $(0.012)$ & $(0.012)$ & $(0.012)$ & $(0.012)$ & $(0.014)$ \\
\hline \multirow[t]{2}{*}{ MUNI*POST 1987} & $0.056^{* * *}$ & $0.060 * * *$ & $0.061 * * *$ & $0.059 * * *$ & $0.062 * * *$ \\
\hline & $(0.012)$ & $(0.013)$ & $(0.013)$ & $(0.013)$ & $(0.013)$ \\
\hline \multirow[t]{2}{*}{$\ln (W A G E)$} & -0.010 & -0.012 & -0.013 & -0.011 & -0.013 \\
\hline & $(0.013)$ & $(0.013)$ & $(0.013)$ & $(0.013)$ & $(0.013)$ \\
\hline \multirow[t]{2}{*}{$\ln (N E T M W H)$} & $0.036 * * *$ & 0.067 & 0.076 & 0.060 & 0.078 \\
\hline & $(0.005)$ & $(0.064)$ & $(0.065)$ & $(0.065)$ & $(0.064)$ \\
\hline \multirow[t]{2}{*}{ SCRUBBER } & 0.033 & 0.037 & 0.039 & 0.035 & 0.041 \\
\hline & $(0.026)$ & $(0.025)$ & $(0.025)$ & $(0.026)$ & $(0.025)$ \\
\hline$\rho$ & .75 & .72 & .71 & .72 & .71 \\
\hline
\end{tabular}

$\mathrm{N}=10079 ; 769$ plant-epoch and 19 year effects included.

Estimates corrected for the presence of serial correlation using a Prais-Winsten transformation.

IV estimates use $\ln ($ STATE SALES) as an instrument for $\ln (N E T M W H)$.

Standard errors in parentheses, clustered for correlation within a state-year.

* significant at 10 percent; $* *$ significant at 5 percent; *** significant at 1 percent 
Table 4: Nonfuel Expense Input Demand Estimates with Alternative Specifications of Restructuring Dependent variable: $\ln$ (NONFUEL EXPENSES)

\begin{tabular}{|c|c|c|c|c|c|}
\hline & $(1)$ & $(2)$ & (3) & $(4)$ & (5) \\
\hline & GLS & GLS-IV & GLS-IV & GLS-IV & GLS-IV \\
\hline Independent Variables & Basic & Basic & Law Date & $\begin{array}{l}\text { Retail } \\
\text { Access }\end{array}$ & $\begin{array}{l}\text { Non Utility } \\
\text { Generation }\end{array}$ \\
\hline IOU*RESTRUCTURED & $\begin{array}{c}-0.095 * * * \\
(0.022)\end{array}$ & $\begin{array}{c}-0.051 * * \\
(0.026)\end{array}$ & & $\begin{array}{c}-0.052 * * \\
(0.025)\end{array}$ & \\
\hline IOU*LAW PASSED & & & $\begin{array}{l}-0.022 \\
(0.027)\end{array}$ & & \\
\hline IOU*RETAIL ACCESS & & & & $\begin{array}{c}-0.189 * * * \\
(0.063)\end{array}$ & \\
\hline IOU*HIGH NON & & & & & -0.013 \\
\hline UTILITY GENERATION & & & & & $(0.029)$ \\
\hline MUNI*POST 1992 & $\begin{array}{c}0.057 * * * \\
(0.019)\end{array}$ & $\begin{array}{c}0.069 * * * \\
(0.021)\end{array}$ & $\begin{array}{c}0.082 * * * \\
(0.022)\end{array}$ & $\begin{array}{c}0.068 * * * \\
(0.020)\end{array}$ & $\begin{array}{c}0.079 * * * \\
(0.023)\end{array}$ \\
\hline MUNI*POST 1987 & $\begin{array}{c}0.121 * * * \\
(0.020)\end{array}$ & $\begin{array}{c}0.109 * * * \\
(0.022)\end{array}$ & $\begin{array}{c}0.108 * * * \\
(0.022)\end{array}$ & $\begin{array}{c}0.110 * * * \\
(0.021)\end{array}$ & $\begin{array}{c}0.108 * * * \\
(0.023)\end{array}$ \\
\hline $\ln (N E T M W H)$ & $\begin{array}{c}0.077 * * * \\
(0.011)\end{array}$ & $\begin{array}{c}0.417 * * * \\
(0.090)\end{array}$ & $\begin{array}{c}0.445^{* * *} \\
(0.091)\end{array}$ & $\begin{array}{c}0.379 * * * \\
(0.091)\end{array}$ & $\begin{array}{c}0.454 * * * \\
(0.091)\end{array}$ \\
\hline SCRUBBER & $\begin{array}{c}0.025 \\
(0.038)\end{array}$ & $\begin{array}{c}0.051 \\
(0.050)\end{array}$ & $\begin{array}{c}0.055 \\
(0.053)\end{array}$ & $\begin{array}{c}0.040 \\
(0.048)\end{array}$ & $\begin{array}{c}0.059 \\
(0.053)\end{array}$ \\
\hline$\rho$ & .38 & .33 & .34 & .33 & .34 \\
\hline
\end{tabular}

Estimates corrected for the presence of serial correlation using a Prais-Winsten transformation.

IV estimates use $\ln (S T A T E S A L E S)$ as an instrument for $\ln (N E T M W H)$.

Standard errors in parentheses, clustered for correlation within a state-year.

* significant at 10 percent; ** significant at 5 percent; *** significant at 1 percent 
Table 5: Fuel Input Demand Estimates with Alternative Specifications of Restructuring Dependent variable: $\ln (B T U s)$

\begin{tabular}{|c|c|c|c|c|c|}
\hline & $(1)$ & $(2)$ & $(3)$ & $(4)$ & $(5)$ \\
\hline & GLS & GLS-IV & GLS-IV & GLS-IV & GLS-IV \\
\hline \multirow[t]{2}{*}{ Independent Variables } & Basic & Basic & Law Date & Retail & Non Utility \\
\hline & & & & Access & Generation \\
\hline \multirow[t]{2}{*}{ IOU*RESTRUCTURED } & $-0.014 * * *$ & -0.009 & & -0.009 & \\
\hline & $(0.004)$ & $(0.006)$ & & $(0.006)$ & \\
\hline \multirow[t]{2}{*}{ IOU*LAW PASSED } & & & 0.005 & & \\
\hline & & & $(0.007)$ & & \\
\hline \multirow[t]{2}{*}{ IOU*RETAIL ACCESS } & & & & 0.007 & \\
\hline & & & & $(0.017)$ & \\
\hline IOU*HIGH NON & & & & & 0.005 \\
\hline UTILITY GENERATION & & & & & $(0.008)$ \\
\hline \multirow[t]{2}{*}{ MUNI*POST 1992} & -0.004 & -0.005 & -0.003 & -0.005 & -0.001 \\
\hline & $(0.005)$ & $(0.007)$ & $(0.007)$ & $(0.007)$ & $(0.007)$ \\
\hline \multirow[t]{2}{*}{ MUNI*POST 1987} & 0.004 & 0.000 & 0.000 & 0.000 & 0.000 \\
\hline & $(0.006)$ & $(0.009)$ & $(0.009)$ & $(0.009)$ & $(0.009)$ \\
\hline \multirow[t]{2}{*}{$\ln (N E T M W H)$} & $0.912 * * *$ & $0.969 * * *$ & $0.979 * * *$ & $0.970 * * *$ & $0.978 * * *$ \\
\hline & $(0.004)$ & $(0.034)$ & $(0.035)$ & $(0.036)$ & $(0.034)$ \\
\hline \multirow[t]{2}{*}{ SCRUBBER } & -0.008 & -0.003 & -0.001 & -0.003 & -0.002 \\
\hline & $(0.009)$ & $(0.010)$ & $(0.010)$ & $(0.010)$ & $(0.009)$ \\
\hline$\rho$ & -.08 & .44 & .44 & .44 & .44 \\
\hline
\end{tabular}

Estimates corrected for the presence of serial correlation using a Prais-Winsten transformation.

IV estimates use $\ln (S T A T E S A L E S)$ as an instrument for $\ln (N E T M W H)$.

Standard errors in parentheses, clustered for correlation within a state-year.

* significant at 10 percent; ** significant at 5 percent; *** significant at 1 percent 
Table 6: Labor Input Demand Estimates by Plant Type Dependent variable: $\ln ($ EMPLOYEES)

\begin{tabular}{lcccc}
\hline \hline & $(1)$ & $(2)$ & $(3)$ & $(4)$ \\
\hline & Larger Plants & Smaller Plants & Old Plants & New Plants \\
Independent Variables & $575 \mathrm{MW}+$ & $<575 \mathrm{MW}$ & $<1960$ & $1960+$ \\
\cline { 2 - 5 } IOU*RESTRUCTURED & $-0.030^{* *}$ & -0.031 & -0.025 & $-0.033^{* * *}$ \\
& $(0.015)$ & $(0.020)$ & $(0.020)$ & $(0.012)$ \\
MUNI*POST 1992 & 0.018 & $0.039^{* *}$ & -0.001 & $0.036^{* * *}$ \\
& $(0.016)$ & $(0.015)$ & $(0.023)$ & $(0.012)$ \\
MUNI*POST 1987 & 0.016 & $0.086^{* * *}$ & $0.092^{* * *}$ & $0.039^{* * *}$ \\
& $(0.021)$ & $(0.016)$ & $(0.028)$ & $(0.013)$ \\
In(WAGE) & 0.004 & $-0.021^{* *}$ & -0.034 & -0.005 \\
& $(0.027)$ & $(0.010)$ & $(0.038)$ & $(0.020)$ \\
In(NET MWH $)$ & 0.054 & 0.047 & 0.085 & 0.013 \\
SCRUBBER & $(0.118)$ & $(0.054)$ & $(0.059)$ & $(0.100)$ \\
& 0.068 & -0.027 & -0.001 & $0.055^{*}$ \\
Observations & $(0.043)$ & $(0.019)$ & $(0.031)$ & $(0.032)$ \\
& .71 & .74 & .70 & .73 \\
& 5016 & 5063 & 5113 & 4966 \\
\hline
\end{tabular}

Plant-epoch and year effects included.

All estimates are GLS-IV using a Prais-Winsten transformation for serial correlation and $\ln ($ STATE SALES) as an instrument for $\ln (N E T M W H)$.

Standard errors in parentheses, clustered for correlation within a state-year.

* significant at 10 percent; $* *$ significant at 5 percent; $* * *$ significant at 1 percent 
Table 7: Nonfuel Expense Demand Estimates by Plant Type Dependent variable: $\ln ($ NONFUEL EXPENSES

\begin{tabular}{lcccc}
\hline \hline & $(1)$ & $(2)$ & $(3)$ & $(4)$ \\
\hline \multirow{3}{*}{ Independent Variables } & Larger Plants & Smaller Plants & Old Plants & New Plants \\
IOU*RESTRUCTURED & $575 \mathrm{MW}+$ & $<575 \mathrm{MW}$ & $<1960$ & $1960+$ \\
& $-0.072^{* *}$ & -0.034 & -0.034 & $-0.068^{* * *}$ \\
MUNI*POST 1992 & $(0.029)$ & $(0.032)$ & $(0.036)$ & $(0.025)$ \\
& $0.078^{* * *}$ & $0.061^{* *}$ & 0.019 & $0.080^{* * *}$ \\
MUNI*POST 1987 & $(0.030)$ & $(0.027)$ & $(0.043)$ & $(0.024)$ \\
& $0.052^{*}$ & $0.149 * * *$ & $0.144 * * *$ & $0.102^{* * *}$ \\
In(NET MWH ) & $(0.031)$ & $(0.026)$ & $(0.037)$ & $(0.027)$ \\
& $0.464 * * *$ & $0.342^{* * *}$ & $0.430^{* * *}$ & $0.369^{* * *}$ \\
SCRUBBER & $(0.146)$ & $(0.092)$ & $(0.110)$ & $(0.121)$ \\
& -0.032 & $0.178^{* * *}$ & 0.101 & -0.057 \\
Observations & $(0.057)$ & $(0.066)$ & $(0.063)$ & $(0.058)$ \\
\hline
\end{tabular}

Plant-epoch and year effects included.

All estimates are GLS-IV using a Prais-Winsten transformation for serial correlation and $\ln ($ STATE SALES) as an instrument for $\ln (N E T M W H)$.

Standard errors in parentheses, clustered for correlation within a state-year.

* significant at 10 percent; ** significant at 5 percent; *** significant at 1 percent 
Table 8: Tests for Mean Reversion in Restructuring Effects on Input Demand

\begin{tabular}{|c|c|c|c|c|}
\hline \multirow{4}{*}{ Independent Variable } & \multicolumn{4}{|c|}{ Dependent Variable } \\
\hline & \multicolumn{2}{|c|}{$\ln (E M P L O Y E E S)$} & \multicolumn{2}{|c|}{$\ln ($ NONFUEL EXPENSES) } \\
\hline & *LOW INPUT & ${ }^{*} H I G H$ INPUT & *LOW INPUT & *HIGH INPUT \\
\hline & PLANT & PLANT & PLANT & PLANT \\
\hline IOU*RESTRUCTURED & 0.017 & $-0.100 * * *$ & 0.009 & $-0.118 * * *$ \\
\hline Interaction & $(0.012)$ & $(0.027)$ & $(0.028)$ & $(0.030)$ \\
\hline MUNI*POST 1992 & $0.086 * * *$ & -0.010 & $0.122 * * *$ & 0.006 \\
\hline Interaction & $(0.019)$ & $(0.014)$ & $(0.027)$ & $(0.023)$ \\
\hline MUNI*POST 1987 & \multicolumn{2}{|c|}{$\begin{array}{c}0.063 * * * \\
(0.013)\end{array}$} & \multicolumn{2}{|c|}{$\begin{array}{l}0.109 * * * \\
(0.021)\end{array}$} \\
\hline $\ln (W A G E)$ & \multicolumn{2}{|c|}{$\begin{array}{l}-0.012 \\
(0.013)\end{array}$} & & \\
\hline $\ln (N E T M W H)$ & \multicolumn{2}{|c|}{$\begin{array}{c}0.080 \\
(0.064)\end{array}$} & \multicolumn{2}{|c|}{$\begin{array}{c}0.405 * * * \\
(0.091)\end{array}$} \\
\hline SCRUBBER & $(0.022)$ & 0.024 & \multicolumn{2}{|c|}{$\begin{array}{c}0.042 \\
(0.046)\end{array}$} \\
\hline$\rho$ & \multicolumn{2}{|c|}{.70} & \multicolumn{2}{|c|}{$\begin{array}{c}(0.046) \\
33\end{array}$} \\
\hline
\end{tabular}

$\mathrm{N}=9784 ; 702$ plant-epoch and 19 year effects included.

All estimates are GLS-IV using a Prais-Winsten transformation for serial correlation and $\ln (S T A T E S A L E S)$ as an instrument for $\ln (N E T M W H)$.

Standard errors in parentheses, clustered for correlation within a state-year.

* significant at 10 percent; $* *$ significant at 5 percent; *** significant at 1 percent 
Figure 1: Labor Input Demand Year-Effects by Regulatory Status (Basic GLS-IV Specification)

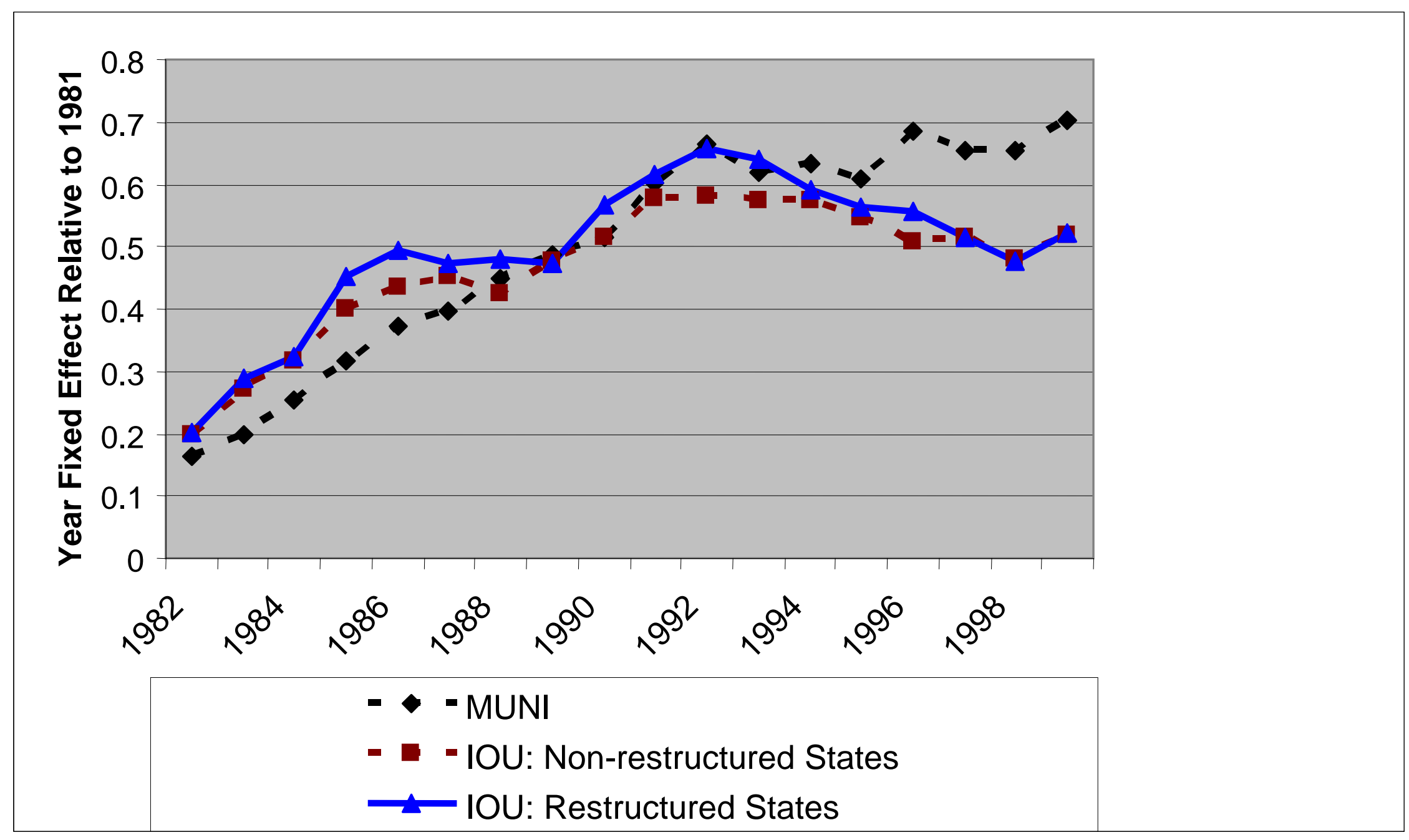


Figure 2: Nonfuel Expense Input Demand Year-Effects by Regulatory Status (Basic GLS-IV Specification)

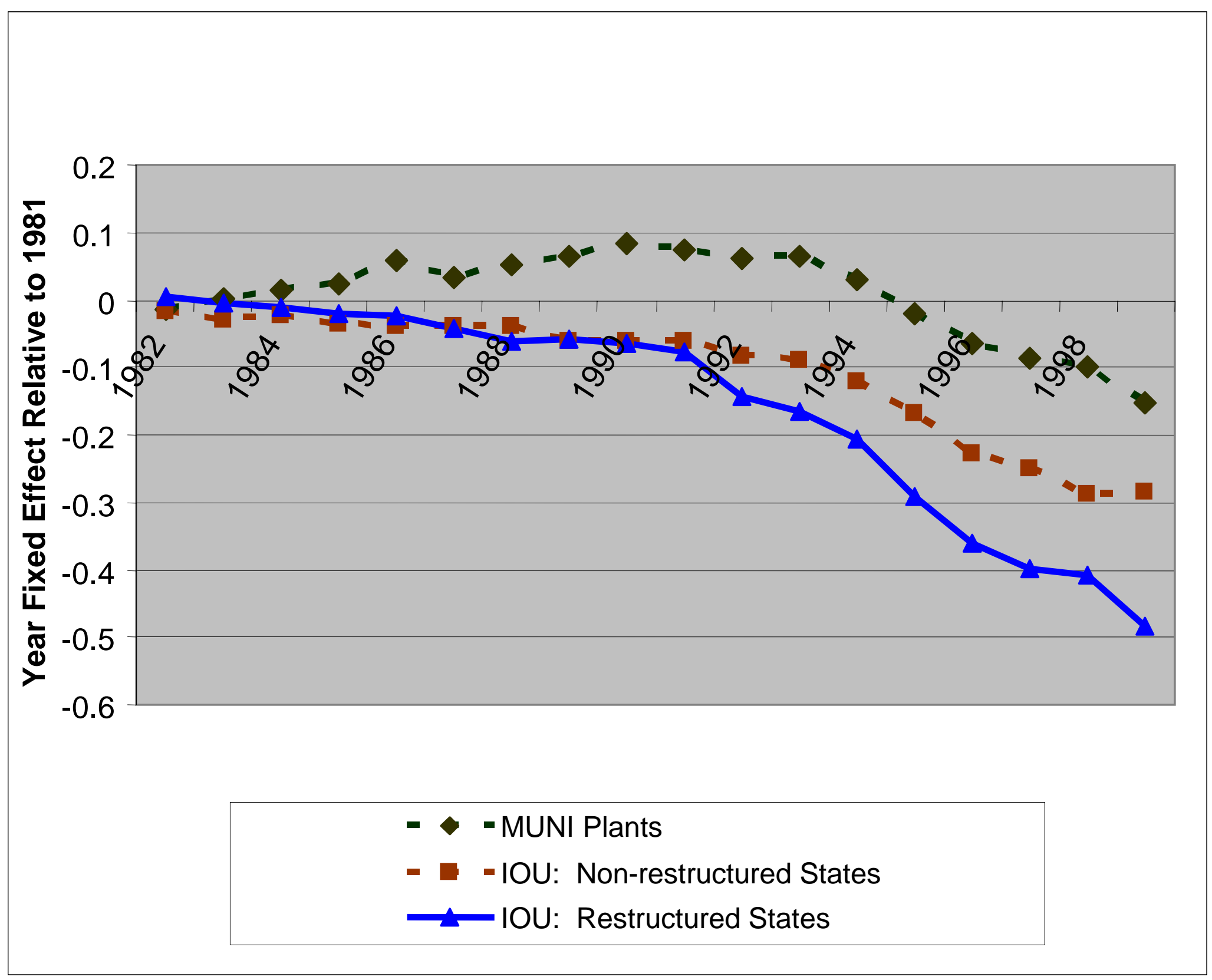




\section{Data Appendix}

\section{Sample Construction:}

This study analyzes productivity for large fossil-fueled steam turbine or combined cycle plants. The core data source is the Utility Data Institute (UDI) O\&M Production Cost Database. UDI develops this from the annual FERC Form 1 (filed by investor-owned utilities), EIA Form 412 (filed by municipal and other government utilities), and RUS Form $7 \& 12$ (filed by electric cooperatives) filings. We construct the sample used in the empirical analysis as follows:

Plant type: We exclude alternative fuel plants (wood, geothermal, waste; 14 plants, 196 plantyears). We restrict the sample to steam turbine (ST) and combined cycle (CC) plants, based on the variable OMPTYPE in the UDI database. This excludes 564 combustion (gas) turbine only (GT) plants, 6487 plant-year observations. ${ }^{53}$

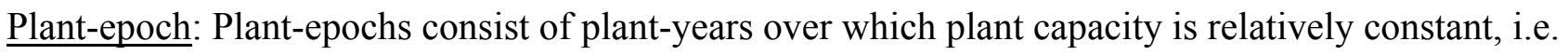
reported capacity changes are less than $40 \mathrm{MW}$ and 15 percent.

Plant size: We retain plant-year observations as long as they are part of a plant-epoch with mean capacity (gross megawatts) above $100 \mathrm{MW}$ and at least 3 years of operations at a scale above 100 MW. The mean capacity test excludes 229 plant-epochs (186 plants, 2142 plant-years); the 3-year operations test excludes an additional 117 plant-epochs (171 plant-years). The latter test also excludes plant-epochs for which we only have one or two years of data, typically plants that add or retire capacity near the beginning or end of our sample period. Excluding these seemed appropriate

\footnotetext{
${ }^{53}$ Most of these are small; the majority report incomplete data. In many cases, these appear (based on plant names and locations) to report information for auxiliary gas turbines located on the same site as units with large steam turbines: e.g., Alamitos, a $1900 \mathrm{MW}$ plant with 6 steam units and Alamitos GT, a $140 \mathrm{MW}$ jet engine unit are separate observations in our dataset. The basic restructuring results are robust to including all large GT plant observations with nonmissing data as additional plants, and to aggregating GT plant data with their identifiable associated base plants (using plant name and location). See column (2) in tables T5 and T6 in the FRW (2007) Technical Appendix.
} 
given plant-epoch fixed effects and the Prais-Winsten-differenced GLS estimation techniques we use.

Incomplete plant data: We drop 274 plant-years with missing or nonpositive output data; 80 plantyears with missing or nonpositive nonfuel expenses; 204 plant-years with missing employment and 289 plant-years with zero reported employees. Observations excluded for missing data do not seem to be directly related to restructuring, and in some cases are less frequent in restructuring states, conditional on year..$^{54}$

Outlier analysis: Stata's dfbeta regression diagnostics were used to ensure that the results are robust to outliers. The dfbeta statistic measures how much a coefficient estimate changes (relative to its standard error) when an observation is omitted. For the basic employment and nonfuel expense model, we calculated dfbeta statistics for all observations for the variables $\ln (N E T M W H)$, SCRUBBER, In(WAGE) for the employment input model, IOU*RESTRUCTURED, MUNI*POST 1992, and MUNI*POST 1987. We excluded 148 observations that moved coefficient estimates in either or both of the employment or the nonfuel regressions by more than 0.1 standard errors. We found little evidence of a pattern in the observations that are dropped this way. For instance, we drop at least 4 observations from every year, and the most observations dropped from any year are 21 from 1998. These deletions change the coefficient point estimates relatively little and serve mainly to clean the data of extreme outliers that inflate the standard errors, as reported in columns (3) and (4) of our Technical Appendix tables T5 and T6. We note that the coefficient on $I O U^{*} R E S T R U C T U R E D$ in the labor input equation changes only slightly (from 0.31 in our basic

\footnotetext{
${ }^{54}$ For example, regression of the percent of plants in a state-year observation with missing or zero employee data on time since restructuring indicator ( $\mathrm{min}(0$, the number of years since the start of formal hearings in the state), year dummy variables, and state fixed effects suggests that the percentage of such missing values actually decreases following restructuring.
} 
specification on the trimmed sample to 0.26 in the untrimmed sample) though it is significantly distinguishable from zero only at the 11 percent level for the untrimmed sample.

The resulting basic dataset consists of 10,079 observations on 647 plants, allocated to 779 plant-epochs.

Fuel Input Dataset: The fuel input dataset begins with the basic dataset described above. We eliminate observations with missing fuel data and apply Stata's dfbeta regression diagnostics to an estimate of the fuel input equation, using a process and thresholds similar to that described for employment and nonfuel expenses. This resulted in deletion of an additional 77 observations. Since most of the analysis that we report in the paper is based on the employment and nonfuel specifications and since the fuel data appear considerably noisier, this smaller dataset is used only for the fuel input analysis. It consists of 10,002 observations on 646 plants, 778 plant-epochs. 
Table A1: Summary of Variables ( $\mathrm{N}=10079$ unless otherwise noted)

\begin{tabular}{|c|c|c|}
\hline Variable & Definition & $\begin{array}{c}\text { Mean } \\
\text { (Standard Deviation) }\end{array}$ \\
\hline \multicolumn{3}{|c|}{ Output and Input Variables } \\
\hline $\ln (N O N F U E L$ EXPENSE) & $\begin{array}{l}\text { ln }(\text { Annual non fuel production } \\
\text { expenses }(\$)) \text {, calculated as the total } \\
\text { production expense less fuel } \\
\text { expense. }\end{array}$ & $\begin{array}{l}16.036 \\
(0.940)\end{array}$ \\
\hline $\ln (E M P L O Y E E S)$ & $\begin{array}{l}\text { ln (Annual mean number of } \\
\text { employees) }\end{array}$ & $\begin{array}{c}4.739 \\
(0.815)\end{array}$ \\
\hline $\ln (B T U)$ & $\begin{array}{l}\ln (\text { Total of the total btus of fuel } \\
\text { consumption). Calculated as (tons of } \\
\text { coal } * 2000 \mathrm{lbs} / \mathrm{ton} * \text { btu/lb) }+ \\
\left(\text { barrels of oil } 42 \mathrm{gal} / \mathrm{barrel}{ }^{*} \mathrm{btu} / \mathrm{gal}\right) \\
+\left(\mathrm{Mcf} \text { gas*1000 cf } / \mathrm{mcf}^{*} \mathrm{btu} / \mathrm{cf}\right) \text {. } \\
\text { These use reported annual plant- } \\
\text { specific btu content of each fuel. } \\
(N=10002)\end{array}$ & $\begin{array}{l}30.547 \\
(1.291)\end{array}$ \\
\hline $\ln (N E T M W H)$ & ln (Annual net MWh generation ) & $\begin{array}{l}14.329 \\
(1.396)\end{array}$ \\
\hline \multicolumn{3}{|c|}{ Utility and Restructuring Variables } \\
\hline$I O U$ & $\begin{array}{l}1 \text { for plants classified as IOU, } \\
\text { holding, or private companies; } 0 \\
\text { otherwise. }\end{array}$ & 0.802 \\
\hline MUNI & $\begin{array}{l}1 \text { for plants owned by utilities } \\
\text { classified as government or } \\
\text { cooperative utilities; } 0 \text { otherwise. }\end{array}$ & 0.197 \\
\hline IOU*RESTRUCTURED & $\begin{array}{l}1 \text { for IOU plants in states that } \\
\text { restructured, beginning in the year } \\
\text { of the first formal hearing; } 0 \\
\text { otherwise. }\end{array}$ & 0.108 \\
\hline IOU*LAW PASSED & $\begin{array}{l}1 \text { for IOU plants in states that } \\
\text { restructured, beginning in the year } \\
\text { that legislation was enacted; } 0 \\
\text { otherwise. }\end{array}$ & 0.041 \\
\hline IOU*RETAIL ACCESS & $\begin{array}{l}1 \text { for IOU plants in states that } \\
\text { restructured, beginning in the first } \\
\text { year of retail access; } 0 \text { otherwise. }\end{array}$ & 0.006 \\
\hline MUNI*POST 1987 & $\begin{array}{l}1 \text { for MUNI plants in years } 1988 \text { - } \\
\text { 1999; } 0 \text { otherwise. }\end{array}$ & 0.133 \\
\hline MUNI*POST 1992 & $\begin{array}{l}1 \text { for MUNI plants in years } 1993- \\
1999 ; 0 \text { otherwise. }\end{array}$ & 0.074 \\
\hline $\begin{array}{l}\text { IOU*HIGH NON } \\
\text { UTILITY GENERATION }\end{array}$ & $\begin{array}{l}1 \text { beginning in } 1993 \text { for IOU plants } \\
\text { in states with above median } \\
\text { penetration of nonutility generating } \\
\text { plants in } 1993 ; 0 \text { otherwise. }\end{array}$ & 0.103 \\
\hline
\end{tabular}




\begin{tabular}{|c|c|c|}
\hline LOW INPUT & $\begin{array}{l}1 \text { if plant mean residual from the } \\
\text { relevant input use regression for } \\
1981-1992 \text { period is below zero; } 0 \\
\text { otherwise }(N=9784) \text {. }\end{array}$ & $\begin{array}{c}0.500 \\
(0.500)\end{array}$ \\
\hline HIGH INPUT & $\begin{array}{l}1 \text { if plant mean residual from the } \\
\text { relevant input use regression for } \\
1981-1992 \text { period is above zero; } 0 \\
\text { otherwise }(\mathrm{N}=9784) \text {. }\end{array}$ & $\begin{array}{c}0.500 \\
(0.500)\end{array}$ \\
\hline \multicolumn{3}{|l|}{ Other Variables } \\
\hline SCRUBBER & $\begin{array}{l}1 \text { if there is an FGD scrubber at the } \\
\text { plant; } 0 \text { otherwise. }\end{array}$ & 0.132 \\
\hline $\ln (W A G E)$ & $\begin{array}{l}\text { Bureau of Labor Statistics annual } \\
\text { wage bill divided by total } \\
\text { employment calculated at the state- } \\
\text { year level separately for IOU and } \\
\text { MUNI plants. Numbers are imputed } \\
\text { for MUNI plants in } 18 \text { states over } \\
\text { various years and for IOU plants in } 6 \\
\text { states from 1997-1999. }\end{array}$ & $\begin{array}{l}10.532 \\
(.335)\end{array}$ \\
\hline \multicolumn{3}{|c|}{ Plant Characteristic Variables } \\
\hline LARGER & $\begin{array}{l}1 \text { if the plant capacity (Gross MW) is } \\
\text { at least } 575 \mathrm{MW} .\end{array}$ & $\begin{array}{c}0.498 \\
(0.500)\end{array}$ \\
\hline SMALLER & $\begin{array}{l}1 \text { if the plant capacity (Gross MW) is } \\
\text { less than } 575 \mathrm{MW} \text {. }\end{array}$ & $\begin{array}{c}0.502 \\
(0.500)\end{array}$ \\
\hline$O L D$ & $\begin{array}{l}1 \text { if the youngest unit at the plant } \\
\text { entered service before } 1960 \text {. }\end{array}$ & $\begin{array}{l}.507 \\
(.500)\end{array}$ \\
\hline$N E W$ & $\begin{array}{l}1 \text { if the youngest unit at the plant } \\
\text { entered service in } 1960 \text { or later. }\end{array}$ & $\begin{array}{l}.493 \\
(.500)\end{array}$ \\
\hline \multicolumn{3}{|c|}{ Economic and Weather Variables } \\
\hline $\ln (S T A T E$ SALES) & $\begin{array}{l}\text { In (Total state electricity } \\
\text { consumption by year in } \\
\text { gigawatthours) }\end{array}$ & $\begin{array}{l}11.184 \\
(0.851)\end{array}$ \\
\hline ANNUAL_HDDAYS & $\begin{array}{l}\text { Population-weighted heating degree } \\
\text { days for each state-year (use MD for } \\
\text { DC); } N=10069 \text {. }\end{array}$ & $\begin{array}{l}4399.468 \\
(2138.744)\end{array}$ \\
\hline ANNUAL_CDDAYS & $\begin{array}{l}\text { Population-weighted cooling degree } \\
\text { days for each state-year (use MD for } \\
\text { DC); } N=10069 \text {. }\end{array}$ & $\begin{array}{c}1432.163 \\
(1.396)\end{array}$ \\
\hline
\end{tabular}




\section{Data Sources:}

Plant characteristics and operating data: UDI O\&M Production Cost Database

Wages: U.S. Department of Labor, Bureau of Labor Statistics. Industry state-level annual wage bill divided by industry total employment.

Electric utility wages: SIC Industries 4911.

Comparable sector wages: Average over SIC industries 4923-4925 (natural gas distribution), 4953 (hazardous waste treatment), and 2911 (petroleum refining).

Utility ownership: UDI Utility Datapak Book, 1997.

Restructuring variables: Restructuring status and timing is compiled from a review of

(1) U.S. Department of Energy, Energy Information Administration (EIA), "The Changing Structure of the Electric Power Industry: An Update, 12/96"

(2) EIA, "The Changing Structure of the Electric Power Industry: 2000 An Update"

(3) EIA, "Status of State Electric Industry Restructuring Activity," Timeline as of July 2002

(4) Edison Electric Institute "Electric Competition in the States" February, 2001

(5) National Association of Regulatory Utility Commissioners (NARUC), "Utility Regulatory Policy in the United States and Canada, Compilation," 1994 - 1995, and 1995 - 96

(6) The Council of State Governments, "Restructuring the Electricity Industry," 1999

(7) State Public Utility Commission websites, relevant legislation and reports.

$\underline{\text { State demand data and instruments: }}$

State electricity sales by year: Sales to Ultimate Customers from EIA's "Electric Sales and Revenue," Table 6, and EIA's "Electric Power Annual," Tables 117 and 90, various years. Heating and cooling degree days: Population-weighted heating and cooling degree days by stateyear (using Maryland for Washington, D.C.) are from U.S. Dept. of Commerce, National Oceanic 
and Atmospheric Administration, Historical Climatology Series, "Monthly State, Regional, and National Heating Degree Days Weighted By Population,” various years. 